\title{
LA IGLESIA PARROQUIAL DE GILENA EN EL TRÁNSITO DEL SIGLO XIX AL XX (1874-1928)
}

\author{
Jorge Alberto Jordán Fernández \\ Doctor en Historia
}

\section{INTRODUCCIÓN}

Este artículo trata de poner de manifiesto las transformaciones producidas en la iglesia parroquial de la Purísima Concepción de Gilena entre los años 1874 y 1928 analizando los datos contenidos en varios inventarios de dicha iglesia realizados durante el periodo de referencia.

Comienza el estudio dando unas breves pinceladas sobre lo que fue el lugar de Gilena durante la época moderna y hasta los primeros decenios del siglo XX; después realizamos un apretado resumen del devenir histórico de la parroquia de Gilena durante el periodo estudiado; el punto central del trabajo es el análisis de los tres inventarios de la parroquia que hemos localizado en el archivo del arzobispado de Sevilla y las conclusiones derivadas de dicho análisis en cuanto a los cambios producidos en el patrimonio de este iglesia en aquellos años.

\section{GILENA: DE CORTIJO A LUGAR (SS. XVI-XX)}

A mediados del siglo XVI, Gilena era un cortijo, o más exactamente varios, dependiente de la jurisdicción de la villa de Estepa, cabeza de 
una de las encomiendas que la orden militar de Santiago poseía en Andalucía; la mención más antigua de Gilena que hemos localizado se contiene en el Libro de las Ordenanzas Municipales de Estepa aprobado por el concejo de la villa el 5 de agosto de 1534, en cuya ordenanza 22 se dice textualmente: ${ }^{1}$

Ítem ordenaron y mandaron que no se den ni ocupen por nadie toda la tierra que está desde el camino que va al cortijo de Gilena la Baja, como van a Gilena a la mano izquierda, hacia la Acebuchosa, y hasta la dehesa y hasta la roza de Alonso Aguilar y hasta el Moralejo, según que está amojonado y se amojonó y señaló en cierto amojonamiento y visitación que se hizo en once días del mes de febrero de mil quinientos y treinta y cuatro años (...) por el provecho que de ello viene para los pastores de los ganados y entradas y salidas a las fuentes de Gilena $y$ Roya y el Moralejo.

Unos años más adelante, en la documentación generada a partir de 1554 con motivo de las averiguaciones que se realizaron entonces para valorar la encomienda santiaguista estepeña de cara a su eventual enajenación por la corona, vuelve a citarse el cortijo o cortijos de Gilena; así en el informe redactado para la descripción, medición y tasación de la encomienda estepeña por los jueces reales, Alonso Ortiz y Francisco de Santiago, en octubre de 1554, se dice que estos jueces fueron al Ojo del Agua, a unas casas que dicen Gilena la Alta, y de alli fueron, el agua adelante, hasta llegar a las huertas de Aguadulce y arroyo rio Salado, donde se parten los términos de Estepa y Osuna. ${ }^{2}$ En otro informe posterior sobre la valoración de la encomienda estepeña, de abril de 1555, redactado por los mismos jueces reales, estos afirmaban que los terrenos que habian visitado les parecian pobres de agua por tener pocos manantiales, entre los cuales citaban el agua proveniente del Ojo de Gilena de la cual se surtían quince molinos y se riega de ella las huertas donde dicen Aguadulce (...) y esta agua es una fuente que sale del cortijo de Gilena la Alta, a la que solian acudir los vecinos de Estepa para lavar sus paños y hacer sus coladas. ${ }^{3}$

\footnotetext{
Rosario GARZA CORTÉS, La villa de Estepa al final del dominio santiaguista, Estepa, 1996, p. 88.

2 GARZA CORTÉS, ob. cit., p. 125.

3 GARZA CORTÉS, ob. cit., pp. 164 y 165.
} 
Como vemos, de las anteriores descripciones puede deducirse que el núcleo poblacional inicial surgió en torno a un manantial de agua, cerca del cual fueron edificándose algunos cortijos y casas. En cuanto a la población que habitaba estos cortijos sabemos que, según el padrón de vecinos elaborado en este mismo contexto el año 1555, el cortijo de Gilena la Alta estaba habitado por 35 vecinos. $^{4}$

En 1559 las villas de Estepa y de Pedrera, con toda su jurisdicción, que incluía los cortijos, fueron vendidas por la corona al banquero genovés Adán Centurión, convirtiéndose a partir de entonces en el estado señorial del marquesado de Estepa, cuyo dominio efectivo se extenderá hasta la abolición de los señoríos a comienzos del siglo XIX.

En 1611, según el repartimiento del servicio ordinario, todavía se seguía llamando Cortijo de Gilena, ${ }^{5}$ siendo en 1627 la primera vez que aparece documentada como lugar, concretamente en un libro sacramental de la parroquia de Santa María de Estepa, donde se anotaba que un tal don Juan de Diego Oranz era cura de la puebla de Gilena. ${ }^{6}$

Para mediados del siglo XVIII contamos con una aceptable descripción del lugar de Gilena gracias a las respuestas que los representantes de sus vecinos dieron a las averiguaciones dimanadas del llamado Catastro de Ensenada; a través de las cuarenta cuestiones planteadas en el interrogatorio y las respuestas dadas por los gilenenses nos enteramos de que el lugar es de señorio y pertenece al marqués de Estepa como aldea suya, con jurisdicción pedánea sujeta en todo a la de dicha villa; y también de que al marqués correspondía el nombramiento de los empleos de justicia y gobernación del lugar y el cobro de los diezmos así como también de los derechos de alcabalas y de correduría y almotacén,

4 Cfr. Rafael G. PEINADO SANTAELLA, "Estepa en la Edad Media (711-1559)", en VV. AA., Actas de las I Jornadas sobre Historia de Estepa, Estepa, 1995, p. 175, n. 120 .

5 El dato en Jesús Ma REINA y José REINA, Aproximación a la Historia de Gilena (siglos XVIII, XIX y XX), Gilena, 2001, p. 24.

6 El dato en José FERNÁNDEZ FLORES, Vere Nullius. La Vicaría de Estepa, Estepa, 2000, p. 286. 
por los cuales se estimaba que percibía anualmente casi 38.400 reales; ${ }^{7}$ la corona percibía por el servicio ordinario y extraordinario 750 reales anuales, que se le reparten por la villa de Estepa, en lo que se consideran sumamente gravados los vecinos, y de paja y utensilios 602 reales; finalmente la iglesia percibía las primicias, cuya cantidad no se especificaba, y el voto de Santiago, percibido por la Iglesia de Santiago, que suponía unos 700 reales al año. ${ }^{8}$

Hacia el año 1751, el lugar de Gilena comprendía un territorio formado por 5.043 fanegas de tierra, en el que se incluian nueve molinos harineros y uno aceitero; estaba habitado por 283 vecinos que moraban en 231 casas habitables (también había 9 casas arruinadas); la mayoría de los habitantes de Gilena se ocupaban en la agricultura, contabilizándose 299 jornaleros (de ellos, 14 milicianos), cuyo jornal diario era de dos reales; también habia algunos artesanos y profesionales liberales; además vivían en Gilena 24 pobres de solemnidad; la población eclesiástica estaba formada por 13 clérigos seculares, de los cuales 7 eran presbiteros y 6 estaban ordenados de menores. ${ }^{9}$

Según los datos reflejados por el censo de Floridablanca de 1787, la población de Gilena ascendía entonces a 1.605 habitantes, entre los que figuraban un cura, un sacristán y un acólito. ${ }^{10}$

7 Los diezmos los poseía la casa del marqués de Estepa en virtud de la carta real de venta otorgada el 12 agosto de 1559 en cuy privilegio se comprenden las jurisdicciones ordinarias eclesiásticas y secular, las alcabalas en virtud de otra carta real de venta fechada en Toledo a 16 de marzo de 1561 y los derechos de correduría y almotacén por carta real de venta otorgada por Felipe III el 27 de marzo de 1717. Cfr. Joaquín Octavio PRIETO PÉREZ, El Marquesado de Estepa (1751) según las Respuestas Generales del Catastro de Ensenada, Madrid, 1996, pp. 195 y 200.

8 Las respuestas fueron dadas por los siguientes vecinos de Gilena: Cristóbal Gutiérrez, alcalde pedáneo; Álvaro García, alguacil mayor; Manuel Muñoz, regidor; Francisco Lebrón Francés, escribano; Juan de Morillas y Alonso Díaz Cejudo, que actuaron como peritos o expertos. Estuvo presente también el cura de Gilena, don Juan de Medina Velasco, presbitero. Cfr. PRIETO PÉREZ, ob. cit., pp. 185-205.

9 Cfr. PRIETO PÉREZ, ob. cit., pp. 19-47 y 185-205.

10 El dato en Margarita REINA y Marcial DE CASTRO, "Panorámica de los procesos histórico demográficos de Gilena desde el siglo XVIII hasta el siglo XX”, en VV. AA., Actas de las IV Jornadas sobre Historia de Estepa. La Vicaría eclesiástica de Estepa, Estepa, 2000, p. 399, quienes, a su vez, lo toman de un trabajo inédito sobre demografia en Gilena de Santiago Rivero Luna. 
En los primeros decenios del siglo XIX, Miñano dice que la población de Gilena estaba formada por 459 vecinos, que correspondian a 2.068 habitantes; el pueblo se extendía por la falda de unas sierras donde nace un excelente manantial de aguas cristalinas que llaman el Ojo de Gilena, con la que se surte el pueblo, y el sobrante riega sus buenas huertas y da movimiento a los molinos harineros que tiene a corta distancia de la población. ${ }^{11}$

Más completos son los datos que aporta Madoz para mediados del siglo XIX: tenía Gilena entonces 403 vecinos, lo que equivalía a 1.688 almas o habitantes; ${ }^{12}$ estos habitaban en 466 casas, todas bajas, sin guardar el mejor orden en su distribución interior, repartidas en 11 calles, incómodas en su mayoría, por el mal estado del empedrado, y 3 plazas, dos de ellas de figura irregular, de mediana extensión, y la tercera cuadrada aunque pequeña; la localidad contaba con un edificio para el pósito, una casa consistorial, una cárcel, muy pequeña, dos escuelas de niños y otras dos de niñas. La superficie del término municipal era de 3.761 fanegas, la mayoría de las cuales estaban dedicadas al cultivo, bien de cereal o bien de olivar, con algunas huertas y viñas, y otra parte eran de chaparral y monte bajo (772 fanegas). Del manantial, casi dentro de la población, de muy buena agua, se surtía el vecindario y los ganados; este manantial formaba un arroyo llamado de Gilena, el cual, en su curso, de este a oeste, atraviesa las calles por medio de zanjas y desagua en el Salado de Osuna, regando once huertas que forman la rivera denominada de Gilena y da impulso por medio de una acequia a 9 molinos harineros, 2 de los cuales se hallan dentro de la población y 7 en el término de Aguas-dulces; además contaba con tres molinos aceiteros, dos en el cortijo de Ípora y uno en el caserío del Carmen. ${ }^{13}$

11 Sebastián de MIÑANO, Diccionario geográfico-estadístico de España y Portugal, Madrid, 1826, t. IV, p. 517.

12 No casan bien estos datos con los reflejados en un padrón realizado por la Vicaría General de Estepa el año 1845 según el cual en Gilena había por aquel entonces 587 vecinos y 2.348 almas, si bien esta última cifra concuerda bastante con el dato reflejado por el censo de 1857 (2.256 habitantes). Cfr. REINA y DE CASTRO, ob. cit., p. 400.

13 Todos estos datos en Pascual MADOZ, Diccionario geográfico-estadistico-histórico de España y sus posesiones de Ultramar, Madrid, 1845-1850 (ed. Facsímil del volumen correspondiente a la provincia de Sevilla: Valladolid, 1986, p. 88). De la hacienda del Carmen dice Madoz que perteneció al convento de carmelitas calzados de la villa de Osuna. 
Según los datos recogidos en la memoria del gobernador de la provincia de Sevilla don Antonio Guerola en 1863, consta que en Gilena vivían entonces 616 vecinos que se correspondian con 2.415 habitantes.

A partir de 1857 contamos con los datos de los censos de población para conocer la evolución de la misma durante el periodo que nos interesa; en el caso de Gilena los reflejamos en el siguiente cuadro: ${ }^{14}$

\begin{tabular}{|l|c|c|c|c|c|c|c|c|}
\hline AÑO & 1857 & 1860 & 1877 & 1887 & 1900 & 1910 & 1920 & 1930 \\
\hline HABIT. & 2.256 & 2.415 & 2.575 & 2.886 & 3.084 & 3.074 & 3.088 & 3.521 \\
\hline
\end{tabular}

Por los datos reflejados en el cuadro puede verse una constante evolución positiva de la población en Gilena durante este periodo y ello a pesar de las dos invasiones de la epidemia de cólera morbo asiático que se vivieron en esta población y que produjeron un notable incremento de la mortalidad. La primera de estas epidemias de cólera asoló el pueblo en 1855 y se cobró la vida de al menos 191 personas entre el 13 de julio y el 6 de septiembre de aquel año; la segunda, menos virulenta, tuvo lugar a partir de octubre de 1890 falleciendo entonces unas cien personas por causa de esta enfermedad. ${ }^{15}$

\section{RESEÑA HISTÓRICA DE LA IGLESIA PARROQUIAL DE GILENA}

Si hay un hecho que caracterice el desarrollo histórico de la iglesia de Gilena hasta bien entrado el siglo XIX es la pertenencia, desde su fundación, a la jurisdicción de la vicaría general de Estepa, un territorio nullius dioecesis, que coincidía con los limites del marquesado de su nombre, regido por un prelado inferior que,

14 Los datos en Francisco CONTRERAS PÉREZ, "La comarca de Estepa a la luz de los censos modernos (1857-1930)", en VV. AA., Actas de las II Jornadas sobre Historia de Estepa. El Marquesado de Estepa, Estepa, 1996, p. 501.

15 Los datos en Francisco MORALES PADRÓN (coord.), Catálogo de los Archivos Parroquiales de la Provincia de Sevilla, Sevilla, 1992, t. I, p. 543; REINA y REINA, ob. cit., pp. 142-145 y en REINA y DE CASTRO, ob. cit., pp. 401-402. 
con título de vicario general y nombramiento del marqués, ejercía la jurisdicción eclesiástica en el mismo, hasta su desaparición e integración en el arzobispado hispalense, como un arciprestazgo más, el año 1874, en virtud de la aplicación de la bula papal Quae diversa promulgada por Pío IX (1846-1878). Los tres vicarios generales de Estepa que hubo en el siglo XIX fueron: ${ }^{16}$ don Pedro José Baena y Núñez ${ }^{17}$ (1805-1836), don Salvador José de los Reyes y García de Lara $^{18}$ (1837-1848) y don Antolín Monescillo y Viso ${ }^{19}$ (1848-1861); a partir de este último año, en que don Antolín fue preconizado obispo de Calahorra- La Calzada, quedó como teniente de vicario interino don Joaquín Téllez de la Torre ${ }^{20}$ quien se convertiria, a partir de 1874 y hasta su fallecimiento en 1883, en el primer arcipreste del partido de Estepa.

16 A don Pascual Fita y Carrillo, que fue vicario de Estepa entre 1787 y 1804, lo consideramos un prelado del siglo anterior.

17 Natural de Estepa (1766), fue ordenado sacerdote en 1790, ejerció de cura en Miragenil (1797-1800), y a partir de dicho año en la parroquia estepeña de San Sebastián, ejerciendo también desde entonces como teniente de vicario general de Estepa por don Pascual Fita; en 1802 se doctoró en derecho canónico por la universidad de Orihuela y tres años después fue nombrado por el marqués de Estepa vicario general, cargo que ejerció hasta su fallecimiento en Manzanares en 1836.

18 Nació en La Zubia (Granada) en 1780. Ordenado sacerdote en 1804, desempeñó los oficios de familiar y secretario de cámara del arzobispo de Granada antes de ser nombrado vicario general de Estepa en 1837, cargo que ejerció hasta el año 1848 , en que fue promovido al obispado de Málaga, de donde pasó a la sede granadina en 1852. Falleció en Granada en 1865.

19 Natural de Corral de Calatrava (1811), realizó los estudios eclesiásticos en el seminario de Toledo, siendo ordenado presbítero en 1836; fue nombrado vicario de Estepa en 1849, cargó que simultaneó con una canonjía en Granada a partir de 1852, que permutó al año siguiente por otra en Toledo, hasta 1861, en que fue consagrado obispo, ocupando sucesivamente las sedes de Calahorra- La Calzada, Jaén (1865), Valencia (1878) y Toledo (1892); en 1884 fue creado cardenal por el papa León XIII. Falleció en Toledo en 1897.

20 Nació en Estepa en 1808, en cuyo convento franciscano profesó en 1824. Fue lector de filosofia en dicho convento hasta la exclaustración (1835). En 1842 fue nombrado teniente de cura de la parroquia de Santa María de Estepa, siendo ascendido a cura propio de la misma el año 1848 y teniente de vicario por don Antolín Monescillo al año siguiente, cargo que continuó ejerciendo interinamente tras la marcha de don Antolin y hasta la supresión definitiva de la vicaría. 


\subsection{De la fundación a la erección de la parroquia (1620-1720)}

El dato más concreto acerca de la antigüedad de la iglesia de Gilena nos lo ofrece el Diccionario de Pascual Madoz, donde se afirma que es de fundación posterior al año 1620, servida por un cura propio y sacristán que nombraba el marqués de Estepa, como patrono, retribuyéndoles con su asignación y costos del clero, como perceptor que era de los diezmos; ${ }^{21}$ ya hemos visto más arriba cómo en cierto libro de la parroquia de Santa María de Estepa se citaba a don Juan de Diego Oranz como cura de la puebla de Gilena en 1627 , lo que vendria a indicar que por entonces ya se ejercía en su iglesia algún tipo de cura animarum.

Qué actividades comprendía dicha cura es algo más complejo de dilucidar; parece quedar fuera de toda duda la celebración de la eucaristía y otras funciones litúrgicas; podemos admitir también que en la iglesia se celebrasen entierros y matrimonios al menos desde el año 1666, como consta de cierto libro sacramental que se custodia en su archivo, siendo cura de ella el presbitero Andrés Muñoz de Estepa, siempre que estas celebraciones se realizaran con licencia del vicario. ${ }^{22}$ Lo que ya es más dificil de admitir es que se celebrasen bautismos antes del año 1720, fecha de la erección de la parroquia, como apunta Fernández Flores: ${ }^{23}$

21 MADOZ, ob. cit., p. 88. En un libro de la parroquia de La Roda se afirma que Gilena se fundó en 1620 (cfr. FERNÁNDEZ FLORES, ob. cit., p. 236), dato que apunta en la misma dirección. Aguilar y Cano también afirma que la iglesia parroquial fue erigida después del año 1620 (cfr. Antonio AGUILAR Y CANO, Memorial Ostipense, Estepa, 1886-1888, t. II, pp. 246-247).

22 El libro en cuestión es el $1^{\circ}$ de Matrimonios, un libro de 277 folios del cual sólo una parte recoge actas matrimoniales; en su primer folio se dice textualmente que en él se contienen los desposorios y velaciones hechas en la puebla de Gilena desde el 19 de septiembre de 1666 hasta el 24 de febrero de 1675 y en su folio 244 comienza el Libro en que se escriben las misas de los testamentos hechos en la puebla de Gilena desde el día 19 de septiembre de 1666 hasta el día 9 de junio de 1676 (cfr. MORALES PADRÓN, ob. cit., pp. 539-540, n. 20). Al parecer existía también otro libro de Desposorios que principia en 1625, pero ya no se conserva (cfr. FERNÁNDEZ FLORES, ob. cit., p. 286).

23 FERNÁNDEZ FLORES, ob. cit., p. 286. 
Sin embargo (...) hay que hacer constar que mucho tiempo antes funcionaba en este pueblo la Parroquia. El estado de la cuestión es el siguiente: por las razones que fueren, bastantes niños nacidos en Gilena eran bautizados en Santa Maria de Estepa. Esto de bautizarse en la Mayor de Estepa era normal, era la Iglesia Madre. Lo que ya no se puede calificar de normal es que se bautizasen algunos en Pedrera. ¿Y los demás que hacian?... pues seguramente se bautizaban en el mismo Gilena.

Y ello por varias razones:

En primer lugar, porque consta documentalmente que al menos hasta el año 1709, apenas once años antes de la erección parroquial, no había pila bautismal en la iglesia de Gilena, tal como afirma el visitador don Juan Clemente Mahuis y Príncipe en el acta de la visita que efectuó al templo el 9 de abril de dicho año. ${ }^{24}$ De aquí que lo habitual fuese que los bautizos de los habitantes de Gilena se celebrasen en Pedrera o en Estepa, donde estaban las parroquias más cercanas, como reconoce el propio Fernández Flores.

En segundo lugar, porque la erección de la parroquia se realizó precisamente a petición de los vecinos y del cura de Gilena, por las causas y motivos que se exponen en las Erecciones de los otros Pueblos de esta Vicaria, ${ }^{25}$ causas seguramente muy parecidas a las expuestas por los vecinos del lugar de Badolatosa: ${ }^{26}$

...por cuyo pedimento hicieron relación diciendo que al dicho Lugar habia venido mucha población y se seguía grande utilidad pública que hubiese Depósito del Santísimo Sacramento y Pila de Bautismo, Óleo y Crisma en la Iglesia de él, y que para ello había decencia en todo lo que era posible al dicho Lugar, y tenía Custodia y relicarios de plata, Sagrario, Palio y Cera, Iglesia decente y pila, y de no haber Sacramento se seguian muy grandes inconvenientes como era notorio...

No parece que tuviera mucho sentido realizar tal petición si para entonces se podian celebrar bautismos en Gilena.

\footnotetext{
Cfr. REINA y REINA, ob. cit., p. 32.

FERNÁNDEZ FLORES, ob. cit., p. 285.

FERNÁNDEZ FLORES, ob. cit., p. 245.
} 
Y, por último, porque a diferencia de lo que ocurre con los matrimonios y los entierros, no hay constancia de que existieran registros de bautismos en el archivo parroquial anteriores a 1720 y no precisamente porque estos hayan desaparecido, como parece afirmar Fernández Flores: pero me alegra que este libro esté como está y no hicieran con él lo mismo que, al parecer, hicieron con el libro de los bautismos realizados en la Parroquia. ${ }^{27}$ Los documentos, en cambio, parecen apuntar en otra dirección, como se lee en el auto del vicario de Estepa inserto al folio primero del primer libro de bautismos de la parroquia de Gilena, fechado el 22 de febrero de 1720: ${ }^{28}$

...debia de haber libro en que se anoten y escriban las partidas de los que recibieren el Santo Sacramento del Bautismo a que se dé la fe y crédito que por derecho se concede desde luego. Su Señoría mandó se use para dicho efecto de este libro, el que se entregará a dicho cura para que lo protocole y ponga en el Archivo, donde están los demás libros de dicha parroquia, y las partidas que de dichos bautismos se escribieren se pondrán y anotarán según práctica y estilo y en la misma conformidad que se pusiere la que se anotará a continuación de este Auto del bautismo que por Su Señoría se ha hecho de una niña legitima de Francisco Lebrón Francés, sacristán de dicha parroquia, y asi lo mando y firmo. Simón, Vicario General de Estepa.

Nótese que el auto no hace referencia alguna a la existencia de un posible registro de bautismos anterior, al mismo tiempo que reconoce la existencia de otros libros en el archivo parroquial de Gilena, seguramente los que hemos citado más arriba de matrimonios y entierros.

Como curiosidad final añadiremos que el 8 de diciembre de 1708 presidió en la iglesia de Gilena la función de la Inmaculada el vicario don Lorenzo de Andújar (1685-1708), pocos días antes de abandonar su cargo y desaparecer para siempre de la escena político-religiosa del marquesado estepeño, vicario

27 FERNÁNDEZ FLORES, ob. cit., p. 289. Se refiere al libro $1^{\circ}$ de matrimonios, al que ya hemos aludido en nota anterior, del que dice que se resiste a cualquier análisis archivístico por donde quiera que se le mire, está incompleto y en estado caótico.

28 FERNÁNDEZ FLORES, ob. cit., p. 286. ¿Será el Francisco Lebrón Francés que aquí se nombra como sacristán de la iglesia la misma persona que en 1751 era escribano de la localidad, según se ha visto en nota más arriba? 
cuyas actuaciones fueron bastante polémicas, como se puso de manifiesto con ocasión de la visita apostólica que precisamente a partir de diciembre de dicho año se realizó a la vicaría estepeña por encargo de la Santa Sede.

\subsection{De la erección parroquial a la supresión de la vicaría (1720-1874)}

En 1720 el cura de Gilena don Alonso Páez de Cabrera, junto a Nicolás de Torres, alguacil mayor, Acisclo Gómez, alcalde de la hermandad, Alonso Díaz Sánchez, mayordomo de fábrica y otros vecinos y moradores del expresado lugar dirigieron un escrito al vicario de Estepa, a la sazón don Simón Miguel de Reina Rengel (1710-1735), solicitando se erigiese en Parroquial la Iglesia del dicho lugar, en respuesta a la anterior solicitud, el vicario, con expresa orden de don Manuel Centurión, VI marqués de Estepa (17081733), visitó dicha iglesia el 22 de febrero de aquel año, que fue jueves, en especial el sagrario y la pila bautismal, que fue bendecida entonces, encontrando todo con la decencia debida y, por tanto, quedando erigida así la nueva parroquia. Ese día se celebró una misa cantada y a continuación de la misma hubo una procesión solemne con el Santísimo Sacramento por las calles del pueblo, con acompañamiento musical y asistencia de muchos sacerdotes y gran concurso de gentes del mismo Lugar y de otros Pueblos. ${ }^{29}$

Algunos años más tarde, a la iglesia primitiva, que era de una sola nave, se le añadió la capilla mayor, que fue bendecida el 7 de enero de 1743 por el entonces vicario de Estepa don Manuel Bejarano y Fonseca (1738-1777), en presencia de don Juan Bautista Centurión, a la sazón VII marqués de Estepa (1733-1785). ${ }^{30}$

Ese mismo dia, el vicario Bejarano le concedió al entonces cura de la parroquia, don Manuel Muñoz del Pozo, el privilegio de una sepultura, para él y sus herederos, en dicha capilla mayor, bendecida

\footnotetext{
Cfr. REINA Y REINA, ob. cit., pp. 34-35 y FERNÁNDEZ FLORES, ob. cit., pp. 285-286.

30 Cfr. REINA Y REINA, ob. cit., p. 42, MORALES PADRÓN, ob. cit., p. 536, n. 3 y FERNÁNDEZ FLORES, ob. cit., p. 289.
} 
por epitafio e inscripción de nombre y apellidos, ${ }^{31}$ privilegio que el mencionado cura no hubo de ejercer por cuanto consta que a los pocos años le fue notificado el traslado, por mandato del marqués, al pueblo de Casariche y su sustitución por el presbitero don Juan Martín de Orellana. ${ }^{32}$ Esta remoción en el curato sin duda debe relacionarse con el litigio que don Manuel Muñoz entabló con las justicias de Gilena reclamándoles el pago de 600 reales anuales por el trabajo de la asistencia a la administración de los Santos Sacramentos, pleito que llegó hasta la Chancillería de Granada y que en 1751 todavía estaba pendiente por no haber caudales para seguirlo. ${ }^{33}$

En 1798 era cura párroco de Gilena don Antonio Diaz, ${ }^{34}$ quien estuvo al frente de la parroquia hasta 1819. Precisamente fue en este último año cuando se edificó la torre de la iglesia, tal como consta en un inventario de la iglesia realizado en 1852: los patronos de ella, que han sido y son los Excmos. Sres. Marqueses de Ariza y Estepa, los cuales Sres. es público en este pueblo han contribuido siempre al socorro de sus necesidades como se verificó por los años de 1819, que dichos Sres. dieron para formar la torre de esta iglesia. ${ }^{35}$

Le sucedió en el cargo don Francisco Machuca Valderrama quien lo ejercería hasta su fallecimiento, acaecido en 1839; ${ }^{36}$ de

31 Cfr. MORALES PADRÓN, ob. cit., p. 536, n. 3.

32 Cfr. MORALES PADRÓN, ob. cit., p. 536, n. 3. La notificación, de la que no podemos precisar fecha, se halla inserta en el Libro $2^{\circ}$ de Bautismos de la parroquia, al folio 122 vuelto.

33 Cfr. PRIETO PÉREZ, ob. cit., p. 199 y REINA y REINA, ob. cit., p. 77.

34 Natural de Gilena, estudió filosofía y teología en la universidad de Osuna entre 1783 y 1786 (cfr. M ${ }^{a}$ Soledad RUBIO SÁNCHEZ, El Colegio-Universidad de Osuna (1548-1824), reedición: Osuna, 2006, p. 339).

35 El inventario fue realizado en 20 de marzo de 1852 por el entonces párroco, don Francisco Cornejo, y se conserva en el archivo de los marqueses de Estepa. Agradecemos esta referencia documental a nuestro buen amigo Moisés Caballero.

36 Nació en Estepa el 9 de febrero de 1790, hijo de Ciriaco Machuca y M ${ }^{\mathrm{a}}$ Teresa Valderrama; en 1807 ingresó en el colegio de la Asunción de Córdoba, donde permaneció hasta la entrada de las tropas francesas, en febrero de 1810, allí estudió artes; en octubre de 1810 ingresó en la universidad de Osuna para estudiar teologia; fue admitido de nuevo en el colegio de la Asunción en octubre de 1814 donde concluyó sus estudios de artes (cfr. RUBIO SÁNCHEZ, ob. cit., p. 352 y Juan ARANDA DONCEL, "Colegiales estepeños en la Asunción de Córdoba durante los siglos XVIII y primeros lustros del XIX”, en VV. AA., Actas de las II Jornadas sobre Historia de Estepa. El Marquesado de Estepa, Estepa, 1996, p. 116). 
este presbítero conservamos su testimonio acerca de la penosa situación económica de su feligresía y, por ende, de la parroquia: ${ }^{37}$

...desde años aqui se ha empobrecido este vecindario en dos de las tres partes de las riquezas, pues éstas han pasado a vecinos pudientes de Estepa $y$ otras partes sin esperanzas de poder volver a redimirlas por la gran distancia que hay de esas a estas, y la otra que ha quedado de nada le sirve más que del derecho de propiedad. (...). El cura ha bajado de su congruidad más de una tercera parte del producido del año común del quinquenio y muchos bautismos y entierros se ve en la necesidad de hacerlos de fiado y sin esperanza de percibir sus emolumentos... y la falta de congruidad de los curas párrocos les produce una degradación para con sus feligreses de la que de ningún modo pueden indemnizarse, pues la necesidad que tanto abunda les constituye en el comprometimiento de socorrer a los miserables.

La situación era tan mala que incluso se produjo un importante robo en la iglesia el año 1838, llevándose los ladrones la cruz procesional, un cáliz, un copón, la crismera o vasito de los crismas y la corona de plata de la patrona. ${ }^{38}$

Tenemos noticia de que en 1837 tenía fijada su residencia en Gilena el presbitero exclaustrado don Juan José Puga, quien había sido guardián del convento de los franciscanos descalzos

Ordenado de menores a título de patrimonio en 1813 con un patrimonio valorado en 69.450 reales formado por varias suertes de tierra aportados por su padre y su tío, Francisco Machuca (cfr. Manuel MARTIN RIEGO, "Ordenados a título de patrimonio en la Vicaría Nullius de Estepa (1800-1874), en Anuario de Historia de la Iglesia Andaluza, vol. VI (2013) pp. 158-183). Fue enterrado en Estepa el 5 de septiembre de 1839 (Archivo de la Parroquia de Santa María de Estepa, Libro de Entierros $n^{\circ}$ 9, f. 256).

37 Manuel MARTÍN RIEGO, "La situación material y económica del clero parroquial de la Vicaria de Estepa a finales del siglo XVIII e inicios del XIX”, en VV. AA., Actas de las I Jornadas sobre Historia de Estepa, Estepa, 1995, pp. 355 y 358.

38 Así se afirma en el inventario de 1852, antes citado. Se da la circunstancia de que en 1703, durante la visita realizada al templo por el visitador del arzobispado Antonio Vinegra, esta corona de plata no se pesó por no poderse quitar, por lo que, si se trata de la misma, los ladrones hubieron de arrancarla a la fuerza, causándole desperfectos a la imagen (cfr. $\mathrm{M}^{\mathrm{a}}$ Encarnación ESCALERA, y Joaquín Octavio PRIETO, "El patrimonio artístico religioso del marquesado de Estepa en los primeros años del siglo XVIII", en VV. AA., Actas de las III Jornadas sobre Historia de Estepa. Patrimonio histórico, Estepa, 1998, pp. 602-603). 
de Antequera, a quien entonces se le concedió licencia para poder celebrar la eucaristía. ${ }^{39}$

El siguiente párroco fue don Francisco Cornejo, religioso franciscano exclaustrado, cuyo nombramiento de cura interino le fue despachado por el marqués de Estepa, como patrono de la iglesia, el 10 de enero de 1840, tomando posesión del curato el 21 del mismo mes; el 1 de mayo de 1849 se le despachó nombramiento como examinador sinodal de la vicaría de Estepa, siendo ya cura propio. ${ }^{40}$ Se da la circunstancia de que este párroco donó a la iglesia de Gilena un terno completo blanco con la condición de que si alguna día volviesen los religiosos de San Francisco de Asis a sus conventos, se entregase al primero que se abriese en el pueblo de Estepa, de donde pertenecía, o a alguno de la Provincia de Sevilla. ${ }^{41}$

El 28 de marzo de 1854 fue nombrado cura propio de Gilena don Antonio José del Valle, que había sido guardián de los franciscanos terceros de Osuna; ${ }^{42}$ no sabemos si fue nombrado para esta parroquia por su experiencia anterior como asistente a los enfermos del cólera en 1834 , pero el caso es que gracias a su testimonio hoy

39 Cfr. Jorge Alberto JORDÁN FERNÁNDEZ, "La exclaustración de 1835-37 en la Vicaría de Estepa", en VV. AA., Actas de las IV Jornadas sobre Historia de Estepa. La vicaría eclesiástica de Estepa, Estepa, 2000, pp. 377.

40 Natural de Pedrera (1779), con quince años profesó en la orden franciscana, estudió filosofia y teología en los conventos de San Pablo de la Breña, Loreto y San Buenaventura. En su orden ejerció de lector en filosofia y teología, siendo elegido guardián de los conventos de Jimena, Estepa y Osuna. Su último destino como religioso fue el convento de Estepa, donde ejercía como confesor de las monjas de Santa Clara, y allí le sorprendió la exclaustración (cfr. JORDÁN FERNÁNDEZ, "La exclaustración..., ob. cit., pp. 366-367).

41 Archivo General del Arzobispado de Sevilla (AGAS), Vicaría de Estepa, legajo 14.556. Inventario de la parroquia de Gilena del año 1874.

42 Nació en Aguilar de la Frontera en 1803, profesando en los padres terceros de San Francisco, donde ejerció como superior del convento de Consolación de la villa de Osuna. Siendo aún religioso, desempeñó interinamente el cargo de teniente de cura de la parroquia de Alameda en 1833 y al año siguiente fue nombrado por el vicario Baena como asistente a los enfermos de cólera. Tras la exclaustración residió en Estepa como sacerdote particular. El 6 de octubre de 1837 fue nombrado sacristán de la parroquia de Herrera, cargo al que renunció en 1843. El 1 de febrero de 1847 se le nombró teniente de cura de la parroquia de San Sebastián de Estepa, curato que ejerció en propiedad a partir del 15 de octubre 1853 y hasta su marcha a Gilena (cfr. JORDÁN FERNÁNDEZ, "La exclaustración..., ob. cit., p. 377). 
queda constancia en los libros parroquiales del comienzo y final de aquella terrible epidemia que asoló al pueblo durante el verano del año siguiente; así el 13 de julio de 1855 anotó en el libro $6^{\circ}$ de entierros (folio 9): Nuestro Padre Dios castiga al pueblo de Gilena con el azote del cólera morbo asiático por espacio de cuarenta días; y el 6 de septiembre de dicho año (folio 50) anotaba: Dios, Nuestro Padre, se da por contento y deja de castigar con el azote del cólera morbo al pueblo de Gilena. Infinitas gracias le sean dadas. ${ }^{43}$ Este sacerdote falleció el 12 de noviembre de $1863 .{ }^{44}$

A partir de entonces ejerció el curato de Gilena como ecónomo el presbítero don Rafael Jiménez Ruiz, ${ }^{45}$ franciscano exclaustrado, a quien le tocó llevar a cabo las diligencias necesarias para la incorporación de la parroquia al arzobispado de Sevilla el año 1874, tras la supresión de la vicaría general de Estepa.

El 14 de febrero de 1874 desde el arzobispado de Sevilla se remitió una carta circular a todos los párrocos de la vicaría general de Estepa cuyas parroquias se iban a incorporar al mismo, instándoles a que en el ofertorio de la misa mayor del domingo, día uno de marzo, se leyera públicamente a los fieles el edicto de supresión de la vicaría e incorporación de la misma al arzobispado; es de suponer, aunque no tenemos el dato concreto, que así lo haría el párroco de Gilena, lo mismo que hicieron los demás párrocos, como nos consta por las comunicaciones de algunos de ellos. ${ }^{46}$

Posteriormente, a partir del 2 de mayo de dicho año, tuvo lugar la visita pastoral del nuevo arciprestazgo de Estepa con vistas a ajustar el funcionamiento de sus parroquias a la normativa

43 Cfr. MORALES PADRÓN, ob. cit., p. 543, n. 35.

44 El dato en MARTÍN RIEGO, "El clero parroquial de la Vicaría de Estepa (siglos XVIII y XIX)", en VV. AA., Actas de las IV Jornadas sobre Historia de Estepa. La vicaria eclesiástica de Estepa, Estepa, 2000, p. 195.

45 Nacido en Estepa en el año 1813, estudió filosofia en el convento del Calvario; después hizo un año de teología y otro de moral en el colegio mayor de San Buenaventura, donde le sorprendió la exclaustración (cfr. JORDÁN FERNÁNDEZ, "La exclaustración..., ob. cit., p. 368).

46 AGAS, Gobierno, Asuntos despachados, legajo 329. Así lo comunicaba el cura de Pedrera, don Lorenzo de Rivas, al arzobispado mediante oficio de fecha 4 de marzo. 
diocesana hispalense; esta visita fue encomendada por el arzobispo de Sevilla, cardenal don Luis de la Lastra y Cuesta (1863-1876), al doctor don Ramón Mauri y Puig, su vicario general.

El 29 de mayo se concluyó la redacción del inventario general de la parroquia de Gilena, realizado con motivo de la visita; el documento está firmado por el párroco, don Rafael Jiménez, el visitador, doctor Mauri, y por el notario de la visita, don Joaquín Álvarez.

Finalmente, el 25 de junio el visitador giró visita oficial a la parroquia de Gilena, inspeccionándola al completo y ordenando se dejara constancia en los libros sacramentales, que el visitador encontró correctos, del edicto de supresión de la vicaría y de los mandatos de la visita relativos a dichos libros: en la diligencia inserta se hizo constar que hacía ya cincuenta y seis años que se practicó la última Santa Visita ${ }^{47} \mathrm{~A}$ partir de entonces, la parroquia de la Purísima Concepción de Gilena pasó a depender jurídicamente del arzobispado de Sevilla formando parte del arciprestazgo de Estepa.

\subsection{Parroquia del arzobispado hispalense (1874-1928)}

Tras la incorporación de la parroquia al arzobispado hispalense, su anterior cura, don Rafael Jiménez continuó al frente de ella, en calidad de ecónomo. Junto a él, los demás miembros de la clerecía gilenense eran los presbiteros don Juan José Guerra Rodríguez, ${ }^{48}$ sacristán y sochantre, y don Antonio Amador Ruiz, capellán y colector, y el tonsurado don Francisco Pedrosa, capellán. ${ }^{49}$

47 Libro $13^{\circ}$ de bautismos, fol. 175 y ss.; Libro $7^{\circ}$ de entierros, fol. 176 vto. y ss. y libro $5^{\circ}$ de matrimonios, fol. 229-234 (cfr. MORALES PADRÓN, ob. cit., pp. 540541, n. 24).

48 Nacido en Gilena en 1840, fue ordenado de menores a título de patrimonio en 1863 con un patrimonio valorado en 40.000 reales compuesto por varias suertes de tierra y aportado por Francisco Díaz García (cfr. MARTIN RIEGO, "Ordenados..., ob. cit., pp. 158-183).

49 AGAS, Gobierno, Asuntos despachados, legajo 329. 
En 1877 llegó a la parroquia don Manuel Díaz Arahal para hacerse cargo de ella también en calidad de cura ecónomo; ${ }^{50}$ al año siguiente de su llegada, se concluyó la edificación de la capilla de la Santísima Trinidad, costeada por don Francisco Díaz García, tal como reza una inscripción en la verja que cierra la misma.

Sabemos que el 10 de mayo de 1884 visitó pastoralmente esta parroquia el entonces arzobispo de Sevilla, fray Ceferino González y Díaz Tuñón (1883-1889), dejando constancia de dicha visita en ciertos mandatos insertos en los libros parroquiales y aprovechando la ocasión para impartir el sacramento de la confirmación. ${ }^{51}$

El año 1886 se hizo cargo de la parroquia, también en calidad de cura ecónomo, don Antonio Gutiérrez y Quevedo, quien en 1888 ganó por oposición este curato, del que tomaria posesión, ya en propiedad, al año siguiente. ${ }^{52}$ Aunque en 1909 se jubiló del curato, siguió residiendo en Gilena, al menos hasta 1919, en que consta su presencia en un funeral. ${ }^{53}$

Entre octubre y noviembre de 1890 la población de Gilena se vio afectada por un nuevo brote de cólera, como ya dijimos más arriba; durante esta nueva epidemia se destacó la labor del presbitero don Manuel Fernández y Fernández, coadjutor de la parroquia de San Sebastián de Estepa, quien estuvo en Gilena prestando muchos auxilios. ${ }^{54}$

El domingo 15 de mayo de 1892 se abrió al culto un nuevo templo en Gilena: la ermita de Nuestra Señora de la Salud, edificada a expensas de don Francisco de Paula Gálvez Gómez sobre unos terrenos de su propiedad, en un extremo de la población, en agradecimiento por haber salvado la vida del cólera en $1890 . .^{55}$

50 El dato en MORALES PADRÓN, ob. cit., p. 543, n. 36.

51 El dato en MORALES PADRÓN, ob. cit., p. 541, n. 25.

52 Cfr. MARTIN RIEGO, "El clero..., ob. cit., pp. 195-196.

Cfr. REINA y REINA, ob. cit., p. 251.

4 Cfr. REINA y REINA, ob. cit., p. 250.

55 Don Francisco de Paula Gálvez Gómez (1844-1919), natural de Gilena, propietario y labrador, vivió en la calle Iglesia, $\mathrm{n}^{\circ} 6$ y era uno de los vecinos más acaudalados del pueblo (Cfr. REINA y REINA, ob. cit., p. 249). 
Inicialmente estaba previsto que la solemne inauguración de la ermita tuviese lugar el 2 de abril de 1892, onomástica de su fundador, pero el retraso en la llegada desde Barcelona de la imagen que se había encargado de la titular de la ermita, a causa del mal estado de las vías férreas, hizo que la ceremonia se retrasase hasta el 15 de mayo. Al año siguiente, tenemos noticias de que se celebraron cultos en la nueva ermita y se había constituido una nueva hermandad: ${ }^{56}$

En Gilena están preparando una novena u octavario a Nuestra Señora de la Salud. Habrá velada la noche del día 20 del presente mes, fuegos artificiales el día 21, cucañas y carreras de cintas el día 22 y solemnes funciones de iglesia durante la novena. Se ha constituido alli una hermandad que cuenta ya con más de 40 hermanos, todos devotos entusiastas de Nuestra Señora de la Salud. ;Bien por la gente de Gilena!

En 1894 las fiestas en honor de la Virgen de la Salud se celebraron a finales de abril, repitiéndose los fuegos artificiales, cucañas, carreras de cintas, iluminaciones y otros festejos, como el año anterior, celebraciones que volvieron a realizarse el siguiente año, pero esta vez coincidiendo con el primer domingo de agosto. ${ }^{57}$

A don Antonio sucedieron en la parroquia don Juan Antonio López (1909-1910) y don José Rodríguez Pérez (1910-1911), quienes apenas estuvieron un año cada uno al frente de la misma. Se da la circunstancia de que el primero de ellos no recibió de su antecesor ningún libro de cuentas de fábrica de la parroquia, motivo por el cual el archivo parroquial no conserva libros de este tipo anteriores al año $1909 .{ }^{58}$

E1 19 de octubre de 1911 tomó posesión canónica en propiedad del curato de Gilena el presbitero don Manuel González Caballero, quien se mantuvo en este cargo al menos hasta el 20 de enero de 1928, fecha en que se redactó el último inventario de la parroquia que nosotros hemos manejado.

56 El Eco de Estepa, $\mathrm{n}^{\circ}$ 546, de 13 de mayo de 1893.

57 Todas las noticias acerca de la fundación de la ermita y las celebraciones en años posteriores en El Eco de Estepa, números 483 (27/02/1892), 488 (02/04/1892), 494 (14/05/1892), 495 (21/05/1892), 595 (21/04/1894) у 613* (27/07/1895).

58 MORALES PADRÓN, ob. cit., p. 545, n. 49. No sabemos a qué pudo deberse esta falta de entrega. 


\section{EVOLUCIÓN DEL TEMPLO PARROQUIAL SEGÚN SUS INVENTARIOS}

\subsection{El templo hasta 1874}

La descripción más antigua que conocemos sobre cómo era el templo parroquial de Gilena se corresponde con el inventario de sus alhajas y efectos que el 9 de julio de 1703 se realizó durante la visita realizada por don Antonio Vinegra, juez eclesiástico; no es documento muy generoso en detalles pero al menos nos permite saber que en aquella fecha existian cuatro imágenes escultóricas, a saber: la Inmaculada Concepción, imagen de vestir, con corona de plata, corona que no se pesó por no poderse quitar, colocada en el altar mayor, donde se supone estaría también un sagrario de madera dorado que se cita el inventario; la imagen de Jesús Nazareno, con tres potencias de plata, se supone que de vestir; la Virgen del Rosario, imagen de vestir, con una corona de plata; y San Francisco de Asís, que suponemos era una escultura de talla, si se trata de la misma que aún hoy se conserva. ${ }^{59}$

Pocos años después, en 1709, concretamente el 9 de julio, con motivo de la visita al templo de don Juan Clemente Mahuis y Príncipe, catedrático de decretales de la universidad de Sevilla $\mathrm{y}$ visitador del arzobispado, se hizo un nuevo inventario que nos proporciona algunos detalles más. De entrada, se dice en el documento que la iglesia era de una sola nave, que no tenía pila bautismal y que en ella existian cuatro altares: ${ }^{60}$

- El altar mayor, con retablo de yeso blanco, ${ }^{61}$ donde estaba colocada la imagen de la Concepción.

59 Cfr. ESCALERA y PRIETO, "El patrimonio..., ob. cit., pp. 602-603. Decimos "se supone", porque algunos autores identifican estas imágenes con las actuales.

60 Cfr. ESCALERA y PRIETO, "El patrimonio..., ob. cit., p. 602.

61 Consta documentalmente que el 26 de septiembre de 1701, Juan Rodríguez Bermudo, vecino de Osuna, se obligó a realizar para esta iglesia en el altar mayor y capilla principal de ella un retablo de yeso cortado por importe 1.500 reales, a pagar por el hermano Juan del Espíritu Santo, sacristán de la iglesia, que los habia juntado de limosna, debiendo acabar dicho retablo para el 8 de diciembre de aquel año (cfr. REINA y REINA, ob. cit., pp. 30-31). 
- El altar de Jesús Nazareno, en el lado del evangelio.

- El altar de la Virgen del Rosario, en el lado de la epístola, frente al del Nazareno.

En la transcripción del documento que conocemos ya no se mencionan más altares, por lo que cabe suponer que el cuarto altar sería el de San Francisco de Asís, si bien no podriamos precisar su ubicación dentro del templo.

Ya hemos dicho más arriba que el 7 de enero de 1743 el vicario Bejarano bendijo la capilla mayor de la iglesia, por lo que es de suponer que la misma se habría labrado poco tiempo antes. También hemos dejado apuntado que en torno al año 1819 se estaba edificando la torre, cuyo coste fue sufragado en parte por la casa de los marqueses de Estepa. Entre ambas fechas se debieron llevar a cabo las obras de ampliación del templo, tal como puede verse hoy.

\subsection{El templo en 1874}

El 29 de mayo de 1874, el entonces cura de la iglesia, don Rafael Jiménez, encargó la realización de un inventario de la misma, según el cual, el interior de la iglesia puede describirse de la siguiente manera: ${ }^{62}$

\section{A. CAPILLA MAYOR}

Con un retablo de madera pintado en blanco, azulado y dorado, que sustituyó al de yeso blanco de comienzos del siglo XVIII; en el centro del retablo estaba la embocadura del camarín donde se veneraba la imagen de la titular, la Inmaculada Concepción,${ }^{63}$ colocada sobre un trono de madera dorado. En el retablo, flanqueando la embocadura,

62 AGAS, Gobierno, Asuntos Despachados, legajo 329.

63 Parece tratarse de la misma imagen que se menciona en los inventarios de principios del siglo XVIII, que hemos visto más arriba (cfr. REINA y REINA, ob. cit., p. 44). 
había sendas esculturas en madera tallada de San Pedro y San Pablo. En el plan de altar, el llamado Sagrario Mayor, cerrado con llave y en su interior un velo azul.

La capilla se cerraba con una verja de hierro con seis perinolas doradas y que tenía una inscripción con el mes y año en que se fundó. ${ }^{64}$

\section{B. LADO DEL EVANGELIO}

A los pies del templo, la llamada Puerta Mayor, de dos hojas, pintada en verde y con su correspondiente cancel.

Entrando por la puerta Mayor, a la izquierda, estaba la capilla del Bautisterio cerrada con puerta de madera, y en su interior una baranda pintada en azul, una pila grande de piedra y otra pequeña, también de piedra, dentro de la anterior, con tapadera de madera en azul; también había una verja con puerta de cristales.

A continuación, en la pared, un cuadro pequeño de Santa Lucía y una pila de agua bendita con su pie, de piedra cipia.

Los altares y capillas que había en este lado, desde los pies del templo a la cabecera eran los siguientes:

Altar de Ánimas: con repisa al aire y retablo pequeño de madera pintado de varios colores; en el centro del retablo un lienzo que representa a San Miguel y el Purgatorio a los pies; pertenecía a la hermandad de Ánimas, que también tenía un túmulo de madera y lienzo de tres cuerpos pintado.

Altar de San Antonio: con retablo de madera en blanco (sin pintar) en cuyo centro había un nicho con puerta de cristal en el que se encontraba la imagen del santo, de talla, con el Niño, de vestir. Este altar pertenecia a don Rafael Garcia.

64 La inscripción decía: Diciembre de 1871 (cfr. VV. AA. Catálogo arqueológico y artístico de la provincia de Sevilla, Sevilla, 1955, t. IV, p.192. 
En el testero de la pared, un cuadro pequeño representando al Señor Amarrado a la Columna; otro cuadro más grande que representaba a Santa Lucía, con marco de cristales y cerco de flores, una farola y vaso de cristal; y un tercer cuadro, de 7 cuartas de largo, con el Señor de la Expiración, con marco antiguo de madera tallado en dorado y colores.

Capilla del Sagrario: cerrada con una verja de hierro con tres perinolas doradas, verja que pertenecía a la hermandad del Santísimo Sacramento; tenía un retablo dorado y colores con talla, en cuyo centro se veneraba la imagen de San Francisco de Asís, ${ }^{65}$ de talla; sobre el altar, de repisa, se situaba el llamado Sagrario menor, con su cortina de tafetán y viso con fleco dorado, corona de madera $y$ dos ángeles sosteniendo la cortina.

En esta misma capilla había una urna o sepulcro de cristal y madera tallada y dorada y en él se encierra la imagen del Salvador, con dos colchones, dos sábanas, dos almohadas y una colcha encarnada, ${ }^{66}$ todo lo cual pertenecía a la Hermandad de Jesús Nazareno.

A continuación se cita el púlpito, de hierro, con escalera de madera y baranda de madera y tornavoz de hierro tallado y en blanco, y al lado, un dosel pequeño de madera, pintado en blanco, con embutidos de espejos, sosteniendo un Crucifijo de madera y cortinillas encarnadas.

Capilla de la Virgen de los Dolores: con un retablo de madera tallada y pintado en varios colores en cuyo centro estaba la embocadura del camarín, con puerta de cristales, donde se custodiaba la imagen de la Virgen, ${ }^{67}$ colocada sobre un trono de madera tallado y de colores; la puerta de acceso al camarín se

65 Al parecer, la misma que se cita en los inventarios de comienzos del siglo XVIII, vistos más arriba (cfr. REINA y REINA, ob. cit., p. 48).

${ }^{66}$ La imagen del Cristo Yacente, del siglo XVIII, con los brazos articulados (cfr. VV. AA., Catálogo..., ob. cit., p. 192).

67 Esta escultura se hizo en el monasterio de Santa Clara de Estepa por sor Ana de San José el año 1772 y fue restaurada en Sevilla el año 1873 por el escultor Gumersindo Jiménez Astorga (cfr. REINA y REINA, ob. cit., p. 45). 
encontraba a la derecha del retablo y por encima de ella había un cuadro con marco de madera representando el Divino Rostro, y encima un Ángel, de talla, suspenso de la pared. Por encima del retablo había una ventana grande de cristales. En el retablo, por encima del altar, había también una urna de caoba con cristales que encerraba los Sagrados Corazones de Jesús y Maria, de talla.

Capilla de la Virgen del Carmen: con su arco de entrada, del que colgaba una lámpara; tenía un retablo de madera dorado y en su centro la embocadura del camarín donde se encontraba la imagen de la Virgen, sobre trono dorado; el altar era de piedra jaspe. Al camarín se accedia desde la misma capilla por unas puertas de madera grandes en blanco.

\section{LADO DE LA EPÍSTOLA}

Entrando por la puerta Mayor, a la derecha, se encuentra un cuadro embutido en la pared con el Señor de la Redención (Jesús Cautivo) con cristal y, a continuación, la puerta de acceso a la torre, pintada en azul.

En el testero de la pared un lienzo, con marco de madera viejo representando El martirio de San Bartolomé, otra pila para el agua bendita, de piedra jaspe, pero sin pie, colocada en la pared, y un cepillo limosnero, embutido en la pared, con puerta de madera.

Los distintos altares y capillas que había en este lado, desde la cabecera del templo a los pies eran los siguientes:

Altar de la Santísima Trinidad: de repisa, con un retablo pequeño de madera formando urna, pintado en blanco y filetes dorados, ${ }^{68}$ en cuyo centro había un cuadro con el Misterio de la Santisima Trinidad con cristales y dos Ángeles a los lados. El altar era propiedad de don Francisco Díaz García.

68 El retablo es viejo, pues sus elementos recuerdan los del periodo barroco, pintado en blanco (VV. AA., Catálogo..., ob. cit., p. 193). 
Capilla del Rosario: tenía un altar de pie con frontal de jaspe y retablo de madera dorado en cuyo centro se veneraba la imagen de talla de la Virgen del Rosario, con el Niño Jesús. ${ }^{69}$ En esta capilla había también tres cuadros (uno de San Juan Nepomuceno, con cristal, otro de la Virgen del Rosario, de cajón, bordado en seda, y otro de Santa Rita) y un Crucifijo, como de tres cuartas de vara, para el Rosario, así como también un nicho y colocada en él la imagen del Evangelista San Juan, de vestir, con un altar de madera.

Todo lo perteneciente a la Virgen del Rosario era propiedad de su hermandad y lo de San Juan era propiedad de la hermandad de Jesús Nazareno. En la capilla había una ventana con cristales y una farola de cristal de la Hermandad del Rosario.

Altar de. Jesús Nazareno: de pie, con frontal de madera pintado, retablo de madera en blanco, en cuyo centro se abría la embocadura al camarín donde se veneraba la imagen de Jesús Nazareno,$^{70}$ de vestir, con corona y potencias de plata, una cruz sobre los hombros y otra que lleva en la procesión. Delante de este altar había una verja de hierro como de dos varas de altura. Todo de la propiedad de la hermandad de Jesús.

Altar del Señor San José: de madera, de pie, con retablo dorado viejo y en el centro un cuadro de lienzo con el Santo, la Virgen y el Niño Jesús, esto es, la Sagrada Familia. Todo propiedad de los herederos de doña Rosalía Macías.

Puerta llamada del Sol: portada lateral, pintada en verde, que también da entrada a la iglesia, con un postigo.

A continuación de esta puerta, había una habitación donde se custodiaba el Monumento para el Jueves Santo, de cuatro columnas y cien luces, propiedad de la hermandad del Santísimo.

69 El retablo del siglo XVIII y de mediano interés y la imagen de la Virgen, interesante escultura del segundo tercio del mismo siglo (cfr. VV. AA., Catálogo..., ob. cit., p. 193); desde luego no es la que se cita en los inventarios de comienzos de aquel siglo, pues alli se dice que era de vestir.

70 Según parece, es la misma que se cita en los inventarios de comienzos del siglo XVIII y procede de Estepa, siendo restaurada en 1873 por el escultor Gumersindo Jiménez Astorga (cfr. REINA y REINA, ob. cit., p. 48). 


\section{NAVE MAYOR}

Había una araña de cristal, de dos varas y media, pendiente del techo, propiedad de la hermandad del Santísimo.

Había también quince escaños o asientos, uno de los cuales tenia grabadas las armas de España y pertenecía al ayuntamiento; tres eran de la hermandad del Santísimo y los once restantes de la hermandad de Jesús Nazareno.

\section{E. SACRISTÍA}

A ella se accedía por una puerta de dos hojas, desde el presbiterio. A la derecha, otra puerta conducía al cuarto de los faroles de la hermandad del Rosario, y en él se encuentran seis con astas nuevos para el Viático y cuatro farolas grandes de la propiedad de la hermandad del Santísimo Sacramento.

En estas dependencias, junto a otros muebles y enseres, también había unas andas para la procesión de $N^{a} S^{a}$ del Rosario, que se realizaba con una imagen de la Virgen con el Niño en sus brazos, de vestir, distinta a la que había en la iglesia, la cual se custodiaba en la casa de don Antonio Amador Ruiz, y que pertenecía a la hermandad del Rosario; ${ }^{71}$ otras andas de caoba para la Virgen del Carmen con sus fundas de madera de pino; dos cajas para conducir los cadáveres de personas mayores y otra pequeña para los párvulos; y una cruz de madera para la ceremonia del Descendimiento.

\section{F. CORO}

Entrando por el cancel a la izquierda, parece que habia una puerta de madera pintada en azul que da entrada al coro, se supone que tras subir una escalera.

71 La imagen de la Virgen, del siglo XVIII, sin interés, pero sí el Niño, de la misma época (cfr. VV. AA., Catálogo..., ob. cit., p. 194). 
El coro tenía una baranda de hierro en la parte que da a la nave del templo y una claraboya de cristales en la pared que daba a la calle.

Había también un órgano con 18 registros, con faltas de pitos y destemplados, tres fuelles de palanca, una banquilla para el organista, un escaño de tres asientos, viejo y quebrado y una rueda con seis campanitas.

\section{G. TORRE}

Entrando por el cancel a la izquierda, en la pared había una puerta del pie de la torre pintada en azul; el acceso a la torre era mediante escalera de caracol de madera; ya en el cuerpo de campanas, había tres campanas, una como de 40 arrobas, otra como de 34 y otra como de 22, ésta cascada; en dicho cuerpo se abrian cuatro balcones: uno de hierro y los restantes de madera pintados en azul.

\subsection{E1 templo en 1886}

Un nuevo inventario de la iglesia se realizó 19 de junio de 1886 , siendo cura de Gilena el presbitero don Antonio Gutiérrez Quevedo; este inventario es más escueto en las descripciones que el anterior, pero las adiciones al mismo que se le realizaron nos van a aportar valiosas noticias sobre las modificaciones realizadas en la iglesia durante estos años: ${ }^{72}$

\section{A. CAPILLA MAYOR}

Con un retablo de madera pintado en blanco, azul y filetes dorados; en el centro del retablo la embocadura del camarín donde se veneraba la imagen de la titular, la Inmaculada Concepción, de candelero, sobre un trono de madera dorado, falto de piezas y en mal estado. En el retablo, flanqueando la embocadura, sendas esculturas en madera tallada de San Pedro y San Pablo.

72 AGAS, Administración, Inventarios, legajo 693 (14.556). 


\section{B. LADO DEL EVANGELIO}

A los pies del templo, la puerta principal, de dos hojas, pintada de color caoba y con su correspondiente cancel, de pino, sin pintar.

Los distintos altares y capillas que habia en este lado, desde los pies a la cabecera eran los siguientes:

Capilla de la Santisima Trinidad: su edificación concluyó hacia 1878, y se hizo a expensas de don Francisco García Diaz, cuya familia la tenía a su cuidado. El retablo de esta capilla era el que en 1874 aparece en la cabecera de la nave de la epístola, propiedad de don Francisco, pero al que se le quitó el cuadro que tenía con la representación del misterio para sustituirlo por uno de talla colocado sobre una nube. Sobre la cornisa del retablo había un cuadro en lienzo con caña dorada, como de dos tercias, representando a San José. La mesa de altar y el frontal eran de mármol de Carrara, probablemente también nuevos, pues no se citan en el inventario de 1874.

Repartidos por las paredes de esta capilla habia cinco cuadros en lienzo de gran tamaño, como de vara y media, con los siguientes temas: El sueño del papa Inocencio III sobre San Francisco de Asis, El arrebato al cielo de San Francisco de Asis en un carro de fuego, Santa María Magdalena, ${ }^{73}$ Santa Águeda y Jesucristo Crucificado; y otro más pequeño, como de media vara, representando la Virgen de los Dolores.

Altar de San Antonio: con retablo de madera pintado en blanco $y$ azul en cuyo centro se encontraba la imagen del santo con el Niño. El altar estaba a cargo de las hermanas doña Josefa y doña Francisca García Morales. Después pasó al cuidado de don Antonio García y en 1909 al de don Francisco Rodríguez Páez, según nos informa la adición al inventario de 31 de mayo de dicho año.

En el testero de la pared, un cuadro, de 7 cuartas de largo, con el Señor de la Expiración, con marco antiguo de madera tallado en dorado y colores.

73 Al parecer, del siglo XVII (cfr. VV. AA., Catálogo..., ob. cit., p. 193). 
Altar de San Francisco: con retablo de madera dorado con su escudo en la parte superior y dos ángeles al pie de las pilastras, en cuyo centro se veneraba la imagen de San Francisco de Asís, de talla, con crucifijo de madera y diadema de plata de ley, peso 4 onzas, y banderola de plata roultz. El altar estaba al cuidado de la Venerable Orden Tercera de San Francisco; después pasó al cuidado de don Juan Gordillo, y en 1909 al de doña Carmen Pozo Vázquez, según la adición al inventario de 31 de mayo de ese año.

A continuación se cita el púlpito, de hierro, con escalera de madera y baranda de hierro, tornavoz de madera tallada.

Capilla de la Virgen de los Dolores: con un retablo de madera tallada y pintado en varios colores. Al lado derecho del altar unas puertas de madera que dan entrada y conducen al camarín de la Virgen, cuya imagen estaba sobre trono de madera tallado.

En el retablo, debajo del camarin habia una urnita de madera de caoba con cristal que encerraba los Sagrados Corazones de Jesús y Maria, de talla. Había además un Ángel, de talla, suspenso sobre la puerta de la escalera del camarín.

Capilla de la Virgen del Carmen y del Sagrario: en esta capilla se quitó el retablo antiguo y se puso uno nuevo, a tenor de la descripción que del mismo se recoge en el inventario: un retablo dorado que tiene sobre la cornisa un cuadro en lienzo que representa el Arcángel San Rafael y en las bases de las columnas otros cuadros pequeños que representan Santos de la Orden de Carmelitas; en un camarin se encuentra la imagen de $N^{a} S^{a}$ del Carmen con su Niño, de candelero, con vestido y manto de tisú. ${ }^{74}$ Los ornamentos de la capilla estaban al cuidado de doña $\mathrm{M}^{\mathrm{a}}$ Josefa García Morales, pero en mayo de 1909 eran custodiados por don Isidro García Cabrera.

La consideramos capilla del Sagrario pues en el inventario se dice que en ella se encuentra también establecida la Hermandad

${ }^{74}$ El retablo podría fecharse hacia 1625, lo mismo que los cinco cuadros pequeños; los santos carmelitas se identifican con Santa Teresa de Jesús, Santa $\mathrm{M}^{a}$ Magdalena de Pazzis, San Ángelo y San Pedro Tomás (cfr. VV. AA., Catálogo..., ob. cit., p. 192). 
del Santisimo Sacramento y sabemos que la anterior capilla sacramental, la de San Francisco, había perdido esta función.

\section{LADO DE LA EPÍSTOLA}

Entrando por la puerta principal, a la derecha, se encuentra una urna embutida en la pared con la imagen del Señor de la Redención (Jesús Cautivo) pintada en cristal [sic].

En el testero de la pared un lienzo, de una vara, con marco de madera en mal estado representando El martirio de San Bartolomé.

Los distintos altares y capillas que habia en este lado, desde la cabecera del templo a los pies eran los siguientes:

Capilla del Rosario: en esta capilla estaba el altar de la Virgen del Rosario, a cargo de su respectiva hermandad, que era de piedra jaspe sobre tres gradas de piedra basta y tenia un retablo de madera tallada y dorado en cuyo centro estaba la imagen de la Virgen, de talla y como de dos varas de alto, con su Niño, colocada sobre trono de madera tallada y dorado, y a los lados las imágenes de Santo Domingo de Guzmán y de San Vicente Ferrer.

En esta capilla estaba también el altar de San Juan Evangelista, de madera, con la imagen del santo colocada en un nicho en la pared, con túnica y capa de terciopelo.

Altar de Jesús Nazareno: la mesa de altar de material con frontal de madera pintado, el retablo de madera en blanco con vidriera, en cuyo centro se abría la embocadura al camarín donde se veneraba la imagen de Jesús Nazareno, de vestir, con túnica de terciopelo, una cruz sobre los hombros de madera plateada con los atributos de la Pasión. El acceso al camarín se hacía por una puerta de madera con dos hojas situada a la izquierda del retablo.

A continuación de este altar estaba el sepulcro de madera tallada y dorada con cristales donde se encuentra la imagen de Jesús con dos colchones de lana, dos sábanas y dos almohadas de hilo blanco, que en 1874 estaba en la capilla de San Francisco de Asís (Sagrario), si bien sabemos que ya entonces pertenecia a la hermandad del Nazareno. 
Los tres altares de Jesús Nazareno, San Juan y Cristo Yacente estaban a cargo de la hermandad de Jesús Nazareno, de la que son el presente año hermano mayor y mayordomo D. Manuel Díaz Joya y D. Francisco Cabrera Montaño.

Había también cuatro tronos para las imágenes de N. P. Jesús, $N^{a} S^{a}$ de los Dolores, San Juan y la Santa Cruz, los dos primeros de madera tallada y los dos últimos de madera lisa

Altar de la extinguida hermandad de Ánimas: con mesa de altar de madera; un retablo pequeño de madera con un lienzo representando a San Miguel y a sus pies el Purgatorio. Este altar estaba en 1874 en la nave del evangelio, y ahora fue colocado frente al altar de Jesús Nazareno.

Altar del Señor San José: de madera, de pie, con retablo dorado y en el centro un cuadro de lienzo con la Sagrada Familia. Según nos informa una adición a este inventario realizada en 31 de mayo de 1909, este altar y retablo, excepto el cuadro de lienzo, fueron quitados de la iglesia y se encontraban entonces en casa y poder de doña Cándida Luna Macías; fue sustituido por otro retablo de madera pintado y altar de madera, que había sido concedido en depósito por la Jurisdicción, es decir, el arzobispado, a don Francisco de Paula Gálvez, y éste, en igual forma, lo cedió temporalmente para dedicarlo a la imagen de San José que había en el templo a cargo de la asociación Josefina. ${ }^{75}$ En este retablo se puso también un Crucifijo de madera en el nicho alto, igualmente a cargo de dicha asociación.

Puerta llamada del Sol: portada lateral, pintada en color caoba, de dos hojas, que también da entrada a la iglesia, con dos postigos. Junto a ella una pila para agua bendita, embutida en la pared, de piedra basta.

A la izquierda de esta puerta, había una habitación, con puerta de madera pintada en verde, donde se custodiaba el Monumento de la hermandad Sacramental.

75 Es posible que se trate de la misma imagen del Santo que se cita en este inventario como de cartón piedra, sin ubicación definida en el inventario de 1886. 


\section{NAVE MAYOR}

Sin que podamos determinar su ubicación, este inventario cita colocados en distintos sitios de la iglesia un lienzo representando a Santa Ana, como de vara y media, con marco tallado, otro lienzo con San José, como de vara, con caña dorada y de poco valor, y una escultura de San José, de cartón piedra, como de vara y tercia.

En una adición a este inventario realizada el 18 de octubre de 1901 se añadieron cuatro cuadros de lienzo, como de vara y media, con los siguientes temas: la Inmaculada Concepción, la Sagrada Familia, Santa Maria Magdalena y San Fernando. ${ }^{76}$

En otra adición posterior, fechada el 31 de mayo de 1909, se nos informa de que la asociación "Apostolado de la Oración" había costeado una imagen escultórica del Sagrado Corazón de Jesús, que se colocó sobre una mesa y encerrada en una urna de madera y cristal, costeado todo por la misma asociación, pero no se precisa la ubicación del mismo.

\section{E. SACRISTÍA}

De sus paredes colgaban dos cuadros de lienzo con marco de madera, de dos varas, en mal estado, representando uno El Purgatorio y el otro a Jesús con la cruz a cuestas.

La imagen de la Virgen del Rosario que se custodiaba en la casa del presbitero don Antonio Amador, como capellán de la hermandad se dice en este inventario que media cinco cuarta de vara, o sea, vara y cuarto, que tenía un Niño, y que ambas imágenes eran de candelero. En mayo de 1909 la imagen pasó a ser custodiada por su hermana, doña Isabel Amador, pues el presbítero había fallecido.

76 El cuadro de San Fernando, interesante y de fines del siglo XVII (cfr. VV. AA., Catálogo..., ob. cit., p. 193). 


\section{F. CORO}

El coro tenía una baranda de hierro en la parte que da a la nave del templo y una claraboya de madera con cristal en la pared que daba a la calle.

Habia también un órgano con 18 registros y fuelles de péndola, en buen uso, banco para el organista y una rueda con seis campanillas. Por una puerta se tenía acceso a la escalera que conducía a la torre.

\section{G. TORRE}

Con una puerta de madera; el acceso a la torre era mediante escalera nueva de madera en forma de caracol que da subida al coro, y partir del coro, otra escalera formada con pasos sobre un espárrago para acceder al cuerpo de campanas; en éste, había tres campanas, una como de 40 arrobas, otra como de 34 y otra como de 22; en dicho cuerpo se abrian cuatro balcones: dos de hierro y dos de madera.

\subsection{E1 templo en 1928}

El 20 de enero de 1928 el entonces cura de la parroquia, don Manuel González Caballero, realizó un nuevo inventario, según el cual la descripción de la iglesia era como sigue: ${ }^{77}$

\section{A. CAPILLA MAYOR}

Con un retablo de madera pintado en blanco, azul y dorado; en el centro del retablo la embocadura del camarín donde se veneraba la imagen de la titular, la Inmaculada Concepción, de vestir, sobre un trono dorado. En el retablo, a los lados de la embocadura, sendas repisas con las imágenes o esculturas en madera tallada de San Pedro y San Pablo, como de una vara.

77 AGAS, Administración, Inventarios, legajo 693 (14.556). 
Había también dos cuadros de lienzo, de dos varas, uno con molduras pintadas y doradas, de poco mérito artístico, uno de ellos representa a Cristo Crucificado y el otro la Sagrada Familia.

\section{B. LADO DEL EVANGELIO}

A los pies del templo, la puerta mayor, pintada en verde, con su correspondiente cancel y dos postigos laterales. A ambos lados del cancel, en la pared, dos pilas para agua bendita, al parecer, la concha con pie de mármol.

Capilla del bautismo: con puerta de entrada de madera pintada en azul; una pila bautismal grande, de piedra, y otra pequeña, también de piedra, dentro de la anterior; colgando de la pared existía un cuadro pequeño de lienzo de media vara de largo que representa a San Juan Bautista bautizando en el Jordán a Jesús, sin ningún valor artístico.

A continuación la puerta de madera que daba acceso a la escalera para subir al coro.

Los altares y capillas de este lado del templo, desde los pies a la cabecera del mismo, eran los siguientes:

Capilla de la Santísima Trinidad: propiedad de los hijos de don Francisco Díaz García, su fundador. Era una capilla cuadrada, bastante espaciosa, con un altar de frente donde se veneraba la Santisima Trinidad, esculturas de talla, en un retablo de madera pintado en blanco y los filetes dorados. El altar es de mármol blanco con pie de altar de madera. En la parte superior del retablo había un cuadro representando San José con el Niño, de mediano mérito artístico.

A la derecha del retablo titular y sobre una mesa había una imagen escultórica de Santa Ana y la Santisima Virgen Niña, de tamaño natural, de madera tallada y pinturas del vestido estofadas. ${ }^{78}$

78 Los autores del Catálogo se hacen eco de la tradición oral según la cual estas imágenes procedian del convento Casa Grande de San Francisco de Sevilla, serían obra de hacia 1630, de escuela sevillana, relacionadas con el círculo de Alonso Cano (cfr. VV. AA., Catálogo..., ob. cit., pp. 192 y 193, n. 9). 
A la izquierda de ese mismo retablo y sobre otra mesa habia una escultura de San Joaquín con la Virgen Niña en los brazos, tamaño natural, de madera tallada y vestidos pintados y estofados. ${ }^{79}$

En el muro de la izquierda de esta capilla se encontraba un altar de madera con la imagen de San Francisco de Paula de madera tallada, ${ }^{80}$ con la particularidad de que este altar no se usaba para decir misa por estar ocupado con el pedestal del santo.

En frente del altar anterior, había otro dedicado al Sagrado Corazón de Jesús, imagen escultórica que estaba colocada en un nicho incrustado en la pared: esta imagen mide vara y media, con pedestal y todo, es escultura moderna, donada por el que fue cura párroco de esta iglesia D. Antonio Gutiérrez Quevedo, el altar es una mesa larga de madera pintada en blanco. ${ }^{81}$

También se hallaba en esta capilla, sobre una mesa de madera más pequeña, una urnita de madera dorada con cristales y dentro un Niño Jesús pequeñito, imagen de vestir. Encima de la urna había una escultura de Cristo Crucificado, como de medio metro, colgado en la pared, bajo un dosel. ${ }^{82}$

Seguian estando colgados de sus paredes los mismos seis cuadros que se mencionan en el inventario de 1886, de los cuales se dice que eran de mediano mérito artístico.

Finalmente, la capilla poseía un enterramiento subterráneo para la familia del fundador y estaba cerrada por una gran verja de hierro.

Altar de San Antonio: a la derecha de San Francisco y dando frente al altar del Sagrario, con retablo todo de mamposteria de yeso, con un nicho en el centro donde se encontraba la imagen del santo con el Niño, de poco más de una vara. El retablo era de yeso moldeado sin pintar ni dorar.

79 Del siglo XVIII y de mediano interés (cfr. VV. AA., Catálogo..., ob. cit., p. 193).

80 Del siglo XVIII y de mediano interés (cfr. VV. AA., Catálogo..., ob. cit., p. 193).

81 Parece que esta imagen no sea la misma que se cita en la adición realizada al inventario de 1886 que, costeada por el "Apostolado de la Oración”, se cita en otro lugar de este inventario de 1928.

82 Del siglo XVII, aunque mal encarnado (cfr. VV. AA., Catálogo.., ob. cit., p. 193). 
Altar de San Francisco: con retablo de madera tallada y dorada, altar de madera de repisa tallado, en cuyo centro se veneraba la imagen de San Francisco de Asis, de madera tallada, como de un metro de altura, con crucifijo en la mano izquierda, y bandera de metal blanco, en la mano izquierda. En el centro del altar un tabernáculo o sagrario antiguo donde están encerradas las anforitas de los santos óleos.

Altar de la Virgen de los Dolores: con un retablo de madera tallada y pintado en varios colores, una urna de caoba pequeña con cristal que encerraba los Sagrados Corazones de Jesús y Maria, de talla. A los lados del altar, en unas repisas dos estatuas, como de vara, de talla, que representan una a San Agustin y la otra a San Luis de Tolosa, obispo. ${ }^{83}$ Al lado izquierdo del altar una puerta que conducía al camarín de la Virgen, cuya imagen, de vestir, estaba sobre trono de madera tallado. Había además un Ángel, de talla, suspenso al retablo y por encima del retablo una ventana grande con cristales.

Capilla de la Virgen del Carmen y del Sagrario: con un retablo de madera tallado y dorado, altar de material con frontalera de una pieza de piedra jaspeada con el escudo del Carmen en el centro. A la izquierda del retablo, la puerta que, por una escalera, conducía al camarin en el que se encuentra la imagen de $N^{a} S^{a}$ del Carmen, como de un metro de alta, con el Niño Jesús en los brazos, es imagen de vestir y está montada sobre un pedestal pintado. En la parte superior del retablo, un cuadro de San Rafael incrustado en el mismo. Junto a la puerta de acceso al camarín, había un cuadro de lienzo de ningún valor artístico que representa a la Virgen del Carmen.

\section{LADO DE LA EPÍSTOLA ${ }^{84}$}

Entrando por la puerta principal, a la derecha, se encuentra una urna embutida en la pared con la imagen del Señor de la Redención (Jesús Cautivo) pintada en cristal [sic].

83 Otros autores las identifican como San Felipe Benicio y San Juan Nepomuceno (cfr. VV. AA., Catálogo..., ob. cit., p. 192).

84 En el inventario a la nave de este lado de la iglesia se la denomina nave del Rosario o nave nueva. 
Los distintos altares y capillas que había en este lado, desde la cabecera del templo a los pies eran los siguientes:

Capilla del Rosario: situada en la cabecera de la nave, en esta capilla estaba el altar de la Virgen del Rosario, de mampostería con frontis de mármol o jaspe en dos piezas y rodeado de una verja de hierro como de dos metros de alta; el retablo de madera tallada y dorado hasta el techo, en cuyo nicho central estaba la imagen de la Virgen, de madera tallada con el Niño en los brazos y como de dos varas de alto.

Entre este altar y el de San Juan había una puerta de madera tallada que conduce a la sacristía.

A continuación de la puerta, estaba el altar de madera de San Juan Evangelista, escultura de vestir, como de vara y media, en un nicho pintado.

Más adelante, la puerta de acceso al camarín de Jesús Nazareno.

Altar de Jesús Nazareno: con el retablo y el altar de madera tallada, en blanco, en cuyo centro se abría la embocadura al camarin, bastante espacioso, donde se veneraba la imagen de Jesús Nazareno, de vestir, de tamaño natural, con la cruz a cuestas, colocada sobre un pedestal o tarima de madera.

Altar de la extinguida hermandad de Ánimas: frente al altar de Jesús Nazareno, de madera tallada y pintado, teniendo en su centro un cuadro de lienzo, como de vara y media de alto, que representa a Cristo Crucificado y al lado derecho la Virgen del Carmen sacando ánimas del Purgatorio.

Altar del Señor San José: con retablo de madera y altar también de madera, tallados y pintados; en la parte superior del retablo habia un nichito con un Crucifijo de pasta, de ningún valor artístico, con cristal por delante; y en el centro del retablo habia otro nicho cobijando una escultura de San José con el Niño de la mano, al parecer de madera tallada ambos.

Puerta grande llamada del Sol: portada lateral, pintada en verde, con un postigo; esta puerta tenía cancel de madera en muy malas 
condiciones. Junto a ella una pila para agua bendita, de piedra blanca.

A continuación de esta puerta había una habitación, con puertas de madera pintada, donde se custodiaba el Monumento para el Jueves Santo.

\section{NAVE MAYOR}

En el lado del evangelio estaba el púlpito, de hierro, con escalerilla de madera y tornavoz de madera tallada.

En esta nave se encontraban cuatro cuadros de lienzo, como de vara y media de alto que representan otros tantos santos de la Iglesia, que suponemos son los mismos cuatro que se mencionan en la adición al inventario de 18 de octubre de 1901, esto es: la Inmaculada Concepción, la Sagrada Familia, Santa Maria Magdalena y San Fernando.

Se ubica también en esta nave el sepulcro con el Cristo yacente, que había estado colocado junto al altar del Nazareno.

En este inventario se dice que había en la iglesia una urna o tabernáculo sin cristales y dentro una imagen del Sagrado Corazón de Jesús, todo sobre una mesa de madera.

\section{E. SACRISTÍA}

De sus paredes colgaban cuatro cuadros de lienzo: uno como de dos varas de largo con marco de madera dorado que representaba el rapto de San Francisco; otro representando el Purgatorio, que ya se citaba en el inventario de 1886; otro representando a Jesucristo, pero en tan mal estado que apenas se conoce la pintura; ${ }^{85}$ y otro con San José, un cuadro ordinario o de batalla sin valor ninguno;

85 Posiblemente fuese el cuadro de Jesús con la cruz a cuestas mencionado en el inventario de 1886. 
finalmente, se menciona una estampa de papel en cuadro pequeño con la imagen de San Juan Nepomuceno.

\section{F. CORO}

El coro tenía una baranda de hierro en la parte que da a la nave del templo y una claraboya redonda en la pared que daba a la calle.

Había también un órgano con 18 registros con falta de pitos y desafinado, un depósito para aire y dos fuelles para alimentar el depósito, una banquilla para el organista y una rueda con varias campanitas para tocarlas cuando se alza en la Santa Misa. Por una puerta se tenía acceso a la escalera que conducía a la torre, de caracol de madera en mal estado.

\section{G. TORRE}

Como de unos 30 metros de alta con cuatro arcos, en cada una de ellos una campana, dos grandes y dos más pequeñas, en buen uso y cuatro balcones, uno en cada arco.

\section{CONCLUSIONES}

La iglesia parroquial de la Inmaculada Concepción de Gilena, de fundación no anterior al año 1620, fue en sus orígenes un modesto edificio de nave única al cual, hacia 1743 , se le añadió la capilla mayor, y probablemente también el camarín de la titular; ya en la segunda mitad del siglo XVIII sufrió profundas transformaciones, añadiéndosele una nave al costado de la epístola y varias capillas en el lado del evangelio.

Los inventarios más antiguos que conocemos de esta iglesia, aunque parcos en detalles, mencionan al menos cuatro imágenes con sus advocaciones, de las cuales parece que en la época que estudiamos se conservaron en el templo al menos tres: la de la Inmaculada Concepción, la de Jesús Nazareno y la de San Francisco de Asís; habiendo desaparecido la de la Virgen del Rosario, que era 
de vestir, siendo posible que se trate de la misma imagen que en 1874 se conservaba en el domicilio particular del presbitero don Antonio Amador Ruiz.

La modificación más importante que sufrió el templo durante la época que estudiamos fue la adición de la capilla de la Santisima Trinidad, edificada hacia 1878 a expensas de don Francisco Díaz García; en ella se colocó el retablo dedicado a este misterio que existía en la nave de la epístola, también propiedad de don Francisco, pero quitándole el lienzo que lo representaba para sustituirlo por una discreta hechura de dicho misterio en madera tallada y policromada. Hasta 1886 este era el único altar que habia en la nueva capilla, adornada con varios cuadros en lienzo, de los que destacamos dos con temática franciscana (representaciones del ciclo de la vida de San Francisco) por su posible procedencia de algún convento desamortizado. Entre 1886 y 1928 es cuando llegan a esta capilla las imágenes más destacadas desde el punto de vista artístico, de procedencia desconocida:

- El grupo escultórico de Santa Ana con la Virgen Niña, cuya ejecución, vinculada al quehacer de Alonso Cano, se sitúa hacia 1630; ya hemos señalado la existencia de una tradición oral en Gilena que lo hace proceder del convento Casa Grande de San Francisco de Sevilla.

- Las imágenes talladas de San Joaquín con la Virgen Niña en brazos y de San Francisco de Paula, ambas del siglo XVIII.

También en este tiempo llegaron a la capilla de la Trinidad una imagen moderna del Sagrado Corazón de Jesús, que fue donada por el cura don Antonio Gutiérrez Quevedo, y una pequeña imagen de vestir del Niño Jesús, dentro de una urna de madera y cristal.

Una transformación menos importante que la anterior fue la sustitución del retablo que cobijaba la embocadura del camarín donde se veneraba la imagen de la Virgen del Carmen, propiedad de don José García. Esta sustitución se produjo entre 1874 y 1886, colocándose entonces un altar cuya factura se sitúa en torno a 1625, probablemente procedente de algún templo carmelita cerrado al culto. 
En relación con este último punto, tenemos constancia de que todavía en 1894 los filipenses de Sevilla, establecidos en el antiguo templo carmelita de San Alberto, se estaban deshaciendo de retablos procedentes de dicha iglesia. Así, consta documentalmente que el entonces capellán de la iglesia estepeña de la Concepción, don José Maximino Téllez Pérez, solicitó al arzobispado hispalense, el 14 de diciembre de aquel año, un pequeño y viejo retablo que lo constituyen algunas molduras, tres cuadros de lienzo y mesa de altar, todo de escaso mérito, el cual, según sus noticias, se hallaba en uno de los almacenes de la Iglesia de San Alberto de esa ciudad, hoy de la Congregación del Oratorio; desde la curia sevillana se pidió informe sobre el particular al prepósito del Oratorio, a la sazón don Manuel de la Oliva, quien contestó el 28 de enero de 1895 que efectivamente existen en esta iglesia, sin uso alguno, el citado altar y lienzos, de los cuales se puede disponer a voluntad de nuestro Emmo. Prelado y en las mismas condiciones que se han tenido presentes respecto de otros objetos e imágenes que existian y se encontraban en esta Iglesia (la negrita es nuestra); el 5 de febrero de dicho año, el arzobispo autorizó la cesión del retablo y cuadros como se pide, en calidad de depósito, pero lo cierto es que dicho retablo nunca llegó a la Concepción de Estepa, pues no consta en los inventarios posteriores que se conservan de dicha iglesia: adónde fue a parar definitivamente el retablo es algo que ignoramos. ${ }^{86}$ Está claro que no se trata del mismo que llegó a Gilena, pues éste lo hizo en una fecha anterior, como hemos visto, pero no hay que descartar que su procedencia sí que fuera la misma.

Otra modificación destacada que se produjo en la parroquia de Gilena es la referida a la sustitución del retablo de madera de San Antonio por uno de mampostería y yeso moldeado, sin pintar ni dorar, sustitución que se llevó a cabo entre 1886 y 1928; desconocemos los motivos habidos para este cambio y más si tenemos en cuenta que en el inventario de 1874 del retablo de madera que habia entonces se dice que estaba en blanco, es decir sin pintar ni dorar, lo que apunta a que se trataba de un retablo reciente, pues en el inventario de 1886 consta que el retablo estaba pintado en blanco y azul.

86 El expediente en cuestión en AGAS, Gobierno, Asuntos Despachados, legajo 04818. 
Finalmente, queremos señalar como cambio importante en esta iglesia la sustitución del antiguo retablo de San José por otro nuevo, de la cual nos informa una adición al inventario de 1886 realizada con fecha de 31 de mayo de 1901; el viejo retablo, de madera y dorado, al cuidado de los herederos de doña Rosalía Macías, que albergaba un cuadro san José con la Virgen y el Niño, fue sustituido en dicha fecha por otro retablo, de madera tallada y pintada, en cuyo nicho principal se colocó una imagen, al parecer de talla, de San José con el Niño de la mano, quedando desde entonces al cuidado de la asociación Josefina. Se da la circunstancia, como apunta la citada adición, de que el nuevo retablo había sido concedido por el arzobispado a don Francisco de Paula Gálvez, en calidad de depósito, quien, en igual forma, lo cedió temporalmente a la parroquia para colocarlo en la nave lateral. Quedémonos con el dato de que las autoridades diocesanas de entonces no sólo cedían retablos a las parroquias sino también a particulares...

\section{APÉNDICE DOCUMENTAL}

\section{INVENTARIO DE LA IGLESIA PARROQUIAL DE LA INMACULADA CONCEPCIÓN DE GILENA (1874) ${ }^{87}$}

Puerta mayor, pintada en verde, con dos postigos, cerraduras $y$ una llave.

Un cancel con dos postigos, picaporte y cerrojos correspondientes, pasadores y una vara de hierro en buen uso.

Capilla del Bautisterio, con puerta de entrada de madera $y$ baranda pintada en azul, una pila grande de piedra y otra pequeña, también de piedra, dentro de la anterior, con tapadera de madera en azul, una verja con puerta de cristales.

Un cuadro pequeño de Santa Lucía.

Una pila de agua bendita con su pie, todo de piedra cipia.

87 AGAS, Gobierno, Asuntos Despachados, legajo 329 (4.833). El inventario está firmado en Gilena el 29 de mayo de 1874 por don Rafael Jiménez, cura propio; el Dr. Mauri, visitador y por don Joaquín Álvarez, notario. 
Puerta de madera pintada en azul que da entrada al coro, con cerradura y llave.

Coro alto, con baranda de hierro, una claraboya redonda a la calle con cristal, un órgano con 18 registros, con faltas de pitos y destemplados, tres fuelles de palanca, una banquilla para el organista, un escaño de tres asientos, viejo y quebrado, una rueda con seis campanitas.

Una puerta para la torre, ésta con escalera de caracol de madera, tres campanas, una como de 40 arrobas, otra como de 34 y otra como de 22, ésta cascada; cuatro balcones en el cuerpo de campanas, uno de hierro y los restantes de madera pintados en azul.

Altar de Ánimas, de repisa al aire, con retablo pequeño de madera pintado de varios colores y en su centro un lienzo que representa a San Miguel y el Purgatorio a los pies (...), todo de la cofradia de Ánimas, como igualmente un túmulo de madera y lienzo de tres cuerpos pintado.

Altar de San Antonio, con retablo de madera en blanco, en su centro un nicho con puerta de cristal y dentro la imagen de San Antonio, de talla, y un Niño, de vestir; (...), todo de la propiedad de don Rafael García (...).

Un cuadro pequeño representando al Señor Amarrado a la columna.

Otro cuadro que representa a Santa Lucía, mayor que el anterior, con marco de cristales y cerco de flores, una farola y vaso de cristal.

Un lienzo como de 7 cuartas de largo, con marco antiguo de madera tallado en dorado y colores, que representa al Señor de la Expiración.

Capilla del Sagrario.

El arco de entrada tiene una baranda o verja de hierro con tres perinolas doradas y paño correspondiente, $y$ en el centro de dicho arco una lámpara de metal pendiente de un pescante de hierro.

Retablo dorado y colores con talla; en el centro la efigie de San Francisco de Asis, de talla, con su velo, donde se halla el Sagrario menor con su cortina de tafetán y viso con fleco dorado, corona de madera y dos ángeles sosteniendo la cortina; altar de repisa (...). 
Los cuatro candeleros y verja de hierro son de la propiedad de la Hermandad del Santísimo Sacramento (...).

En esta misma capilla se halla un sepulcro de cristal y madera tallada y dorada y en él se encierra la imagen del Salvador, con dos colchones, dos sábanas, dos almohadas y una colcha encarnada; todo propiedad de la Hermandad de Jesús.

Un púlpito de hierro, con escalera de madera y baranda de madera y tornavoz de hierro tallado y en blanco. Un dosel pequeño de madera, pintado en blanco, con embutidos de espejos, sosteniendo un Crucifijo de madera y cortinillas encarnadas.

Un confesonario entero de madera con sus puertas.

Capilla de $N^{a} S^{a}$ de los Dolores.

Un retablo de madera tallado y pintado de varios colores, en el centro, una embocadura con puerta o medio punto de cristales y velo encarnado; (...); una urna de caoba con cristal que encierra los Sagrados Corazones de Jesús y Maria; altar de repisa; (..); al lado derecho del altar, unas puertas de madera que dan entrada al camarin de $N^{a} S^{a}$ de los Dolores, donde se encuentra colocada sobre un trono de madera tallado y de colores (...); por encima de la puerta de entrada se halla colocado un cuadro con marco de madera representando el Divino Rostro, y al lado arriba de éste un Ángel de talla, suspenso de la pared; al lado arriba del retablo, una ventana grande de cristales con una cortina encarnada.

\section{Capilla del Carmen.}

Arco de entrada y en su centro una lámpara de metal; retablo de madera dorado, embocadura con su velo; altar de piedra jaspe encarnado; (...), todo propiedad de don José García; unas puertas de madera grandes en blanco que dan entrada al camarin de $N^{a} S^{a}$ del Carmen, en donde se halla colocada sobre su trono dorado.

\section{Crucero. Capilla Mayor.}

Retablo de madera pintado en blanco azulado y dorado, a los lados San Pedro y San Pablo, de talla, embocadura con su velo de seda encarnado; altar mayor con frontaleras de madera, una pintada y otra de caoba (...), puerta de Sagrario Mayor con su llave y en el interior un velo azul; (...); camarín donde se encuentra la imagen de la Purísima Concepción, patrona de la Parroquia, sobre un trono dorado; (...). 
Una verja de hierro con seis perinolas doradas y una inscripción con el mes y año en que se fundó; (...).

Al lado derecho de entrada del cancel se encuentra un cuadro embutido en la pared con el Señor de la Redención con cristal.

Una puerta del pie de la torre pintada en azul, con cerradura y llave.

Un lienzo con marco de madera viejo representando a San Bartolomé.

Una pilita de agua bendita de piedra jaspe, sin pie, colocada en la pared.

Un cepillo para recolectar limosna embutido en la pared, con puerta de madera y llave.

Altar de la Santísima Trinidad, de repisa, con su retablo pequeño de madera formando urna, pintado en blanco y filetes dorados: en el centro un cuadro del Misterio con cristales, dos Ángeles a los lados; (...); todo propiedad de don Francisco Diaz García. Al lado de este altar, una lámpara de metal dorado y una campanita.

Capilla del Rosario, con retablo de madera dorado, en su centro se encuentra $N^{a} S^{a}$ del Rosario, de talla, con Niño Jesús, velo de damasco encarnado, altar de pie con frontal de jaspe (...); un cuadro de San Juan Nepomuceno, con cristal; un cuadro cajón de $N^{a} S^{a}$ del Rosario, bordado en seda y un cuadro de Santa Rita; un Crucifijo como de tres cuartas, para el Rosario.

Un nicho, y colocado en él el evangelista San Juan, de vestir; altar de madera (...).

Todo lo perteneciente a $N^{a} S^{a}$ del Rosario es propiedad de su hermandad y lo de San Juan es propiedad de la Hermandad de Jesús; en esta capilla hay una ventana con cristales y cortina encarnada, una farola de cristal de la Hermandad del Rosario.

Altar de N. P. Jesús, de pie, con frontal de madera pintado, retablo de madera en blanco, embocadura con cristales, hule, mantel y todo lo correspondiente al altar, propiedad de la Hermandad de Jesús; puerta de madera que conduce al camarín donde se encuentra la imagen de Jesús, de vestir, con corona y potencias de plata, una cruz sobre los hombros y otra que lleva en la procesión; una lámpara de metal dorado y delante del altar una verja de hierro como de 2 varas de altura, todo de la propiedad de la Hermandad de Jesús. 
Altar del Señor San José, de madera, de pie, retablo dorado viejo y en su centro un lienzo con el Santo, la Virgen y el Niño Jesús, (...), todo de la propiedad de los herederos de doña Rosalia Macías.

Una puerta llamada del Sol, pintada en verde, que también da entrada a la iglesia, con un postigo, cerradura y llave y un cerrojo.

Inmediato a esta puerta hay una habitación con puerta de madera pintada en verde, donde se custodia el Monumento para el Jueves Santo, de cuatro columnas, con cien luces, propiedad de la hermandad del Santisimo.

En la nave mayor hay pendiente una araña de cristal de dos varas y media, propiedad de la antedicha hermandad.

Quince escaños, uno de ellos, con las armas de España, pertenece al Ayuntamiento, tres de la hermandad del Santisimo y los restantes de la de Jesús.

Dos mesas grandes, una de ellas nueva, de la hermandad de Jesús, y la otra, de la parroquia.

(...)

Dos confesonarios con sus puertas.

(...)

Puerta de dos hojas de madera que da entrada a la Sacristia, a la derecha, una puerta del cuarto de los faroles de la hermandad del Rosario, y en él se encuentran seis con astas nuevos para el Viático y cuatro farolas grandes de la propiedad de la hermandad del Santísimo Sacramento.

Unas andas para la procesión de $N^{a} S^{a}$ del Rosario, de vestir: esta efigie se encuentra en la casa de don Antonio Amador Ruiz, propiedad de su hermandad.

Una mesa de pino con cajón de las hermanas de la escuela.

Una cruz de caoba para los bautismos.

Otra cruz mayor plateada parroquial.

Otra cruz mayor de madera destinada para los niños en los dias de doctrina.

Una mesa grande con dos cajones.

Una taca pequeña para encerrar varios efectos de la parroquia.

Otra taca pequeña pintada en azul, del presbitero don Juan Guerra.

Dos cajoneras para la ropa de la parroquia.

Dos espejos grandes con marcos tallados de madera. 
Una banqueta de madera para orear purificadores.

Dos lienzos grandes con marcos de madera viejos.

Una lámpara de lata con vaso de cristal.

Una mesa de encina para sostener las fuentes de vinajeras y un jarro de agua.

Un aguamanil con llave de metal y percha para las toallas.

Una cortina en la entrada del hueco de la escalera del camarín.

Cuatro faroles con astas viejas y dos de mano para el Viático.

Una cruz de madera con asta para los entierros llanos.

Un asta con columna para procesiones y entierros solemnes.

Un sillón viejo.

Una tablilla para el añalejo y otra para sacar ánima.

Unas andas de caoba para $N^{a} S^{a}$ del Carmen con sus fundas de madera de pino.

Una matraca.

Dos cajas para conducir los cadáveres de personas mayores. Otra pequeña para los párvulos.

Una urna en dorado para el Monumento del Jueves Santo.

Una cruz de madera para el Descendimiento.

Un depósito en dorado para el Reservado.

Baranda de negro con su funda, propiedad de la hermandad de Jesús.

Una puerta de dos hojas de madera para el archivo, colocado en la sacristía.

Ornamentos sagrados.

Blanco.

(...)

Un terno completo, sin paño de medio tisú, que se encuentra en casa del presbitero don Antonio Amador Ruiz: dicho terno fue dejado a esta parroquia por el presbitero don Francisco Cornejo, cura que fue de esta parroquia, con la condición de que si alguna día volviesen los religiosos de San Francisco de Asís a sus conventos, se entregase al primero que se abriese en el pueblo de Estepa, de donde pertenecía, o a alguno de la Provincia de Sevilla. 


\section{INVENTARIO DE LA IGLESIA PARROQUIAL DE LA INMACULADA CONCEPCIÓN DE GILENA $(1886)^{88}$}

Puerta principal de la iglesia.

Se constituye de dos hojas pintadas de color caoba con dos postigos (...) cancel de pino, sin pintar, con dos postigos. Entrando por el postigo de la derecha se encuentra una urna embutida en la pared con la imagen del Señor de la Redención, pintada en cristal.

Cuarto de la torre, puerta de madera (...). Escalera nueva de madera en forma de caracol que da subida al coro y desde éste otra formada con pasos sobre un espárrago que conduce al cuerpo de campanas, de éstas hay tres, una como de 40 arrobas, otra de 34 y la tercera de 22; en la torre cuatro balcones, dos de hierro y dos de madera.

Coro alto con baranda de hierro, una claraboya de madera con cristal que da a la calle (...); un órgano con 18 registros y fuelles de péndola en buen uso; banco para el organista, una rueda con 6 campanillas. Una puerta que da paso a la escalera de la torre.

Puerta llamada del Sol, pintada de color caoba, de dos hojas, que también da entrada a la iglesia, con dos postigos.

Una pila para agua bendita embutida en la pared, de piedra basta; entrando a la izquierda hay una habitación con puerta de madera de dos hojas pintadas en verde donde se encuentra el monumento de la hermandad Sacramental (...).

Capilla Mayor.

Retablo de madera pintado en blanco, azul y filetes dorados, a los lados imágenes de San Pedro y San Pablo. (...). Camarín donde se encuentra la imagen de la Inmaculada Concepción sobre un trono dorado, falto de piezas y en mal estado; la dicha imagen es de candelero (...).

Púlpito de hierro con escalera de madera y baranda de hierro, tornavoz de madera tallada. (...)

88 AGAS, Administración, Inventarios, legajo 693 (14.556). 
En la capilla de $N^{a} S^{a}$ de los Dolores (...) un Ángel de talla suspendido sobre la puerta de la escalera del camarín.

Cuadros colocados en distintos sitios de la iglesia. Un cuadro en lienzo de Santa Ana como de vara y media con marco tallado. Otro del Señor de la Expiración en lienzo con de 7 cuartas con marco antiguo de madera tallado en dorado y colores. Otro de San Bartolomé en lienzo de una vara con marco de madera en mal estado. Un cuadro de San José en lienzo como de vara con caña dorada y de poco valor.

Una imagen de San José de cartón piedra como de vara y tercia.

Sacristía.

Puerta de dos hojas (...). Dos cuadros de lienzo con marco de madera de dos varas, en mal estado, representando uno el Purgatorio y el otro la imagen de Jesús con la Cruz a Cuestas.

(...)

Ropa y alhajas de la Purisima Concepción.

(...)

El vestido de raso y las alhajas de plata y oro como el estandarte $y$ otros objetos se encuentran en poder de $D^{a} M^{a}$ Dolores Muñoz Díaz, como encargada de vestir a la Señora.

(...)

Altar de la extinguida hermandad de Ánimas.

Mesa de altar de madera con repisa de lo mismo.

Retablo pequeño de madera con un cuadro en lienzo representando a San Miguel y a sus pies el Purgatorio. (...)

Capilla de $N^{a} S^{a}$ del Carmen.

Un retablo dorado que tiene sobre la cornisa un cuadro en lienzo que representa el Arcángel San Rafael y en las bases de las columnas otros cuadros pequeños que representan Santos de la Orden de Carmelitas; en un camarin se encuentra la imagen de $N^{a} S^{a}$ del Carmen con su Niño, de candelero, con vestido y manto de tisú. (...). Todos estos objetos al cuidado de su camarera $D^{a} M^{a}$ Josefa García Morales.

En esta capilla se encuentra también establecida la Hermandad del Santísimo Sacramento y a su cuidado los objetos y alhajas que siguen: (...) 
Altar de $N^{a} S^{a}$ del Rosario a cargo de su respectiva Hermandad. Altar de piedra jaspe sobre tres gradas de piedra basta

Retablo de madera tallado y dorado, en el centro la imagen de $N^{a} S^{a}$ del Rosario de talla, como de 2 varas y con su Niño, colocada sobre trono de madera tallado y dorado; a los lados las imágenes de Santo Domingo de Guzmán y de San Vicente Ferrer. (...)

Otra imagen de $N^{a} S^{a}$ del Rosario de cinco cuartas con su Niño y ambas de candelero con las alhajas siguientes: (...). Las imágenes y demás objetos en casa del presbitero D. Antonio Amador, como capellán de la Hermandad.

Altar de $N^{a} S^{a}$ de los Dolores.

Retablo de madera tallado pintado en varios colores. (...). Al lado derecho del altar unas puertas de madera que dan entrada y conducen al camarin de $N^{a} S^{a}$ de los Dolores, colocada sobre trono de madera tallado. En el retablo, debajo del camarín, una urnita de madera de caoba con cristal con los Sagrados Corazones de Jesús y María. (...)

Altar de San Juan.

Mesa de altar de madera. (...). La imagen del Santo colocada en un nicho en la pared, con túnica y capa de terciopelo. (...).

Altar de N.P. Jesús Nazareno.

Mesa de altar de material con frontal de madera pintado. Retablo de madera en blanco, con vidriera. (...). A la izquierda, puerta de madera de dos hojas que conduce al camarín de Jesús, con túnica de terciopelo, una cruz sobre los hombros de madera plateada con atributos de la Pasión. (....). Un sepulcro de madera tallada y dorada con cristales donde se encuentra la imagen de Jesús con dos colchones de lana, dos sábanas y dos almohadas de hilo blanco. Cuatro tronos para las imágenes de N. P. Jesús, $N^{a} S^{a}$ de los Dolores, San Juan y la Santa Cruz, los dos primeros de madera tallada y los dos últimos de madera lisa. Los tres altares anteriores están a cargo de la Hermandad de N.P. Jesús, de la que son el presente año hermano mayor y mayordomo D. Manuel Diaz Joya y D. Francisco Cabrera Montaño.

Altar de San Francisco de Asís.

Un retablo de madera dorado con su escudo en la parte superior y dos ángeles al pie de las pilastras. Imagen del Santo de talla, con 
crucifijo de madera y diadema de plata de ley, peso 4 onzas, y banderola de plata roultz. Mesa de altar de madera.(....). Este altar está a cargo de la VOT de N.P. San Francisco.

Altar de San José.

Lo constituye mesa de madera, retablo dorado y en su centro un cuadro en lienzo de la Sagrada Familia. (...). Este altar a cargo de $D^{a}$ Cándida Luna Macías.

Altar de San Antonio.

Un retablo pintado en blanco y azul en su centro la imagen de San Antonio con el Niño. (...). Este altar a cargo de las hermanas $D^{a}$ Josefa y $D^{a}$ Francisca García Morales.

Capilla de la Santísima Trinidad.

Retablo con dos columnas pintado en blanco con filetes dorados, en su centro el Misterio, de talla, sobre una nube; sobre la cornisa un lienzo con caña dorada de Sr. S. José, como de dos tercias. Mesa de altar y frontal de mármol de Carrara. (...).

Un cuadro de lienzo de Inocencio III, como de vara y media.

Otro de Santa María Magdalena, id. Otro de Jesucristo Crucificado, id.

Otro del tránsito al cielo de San Francisco de Asís, id.

Otro de Santa Águeda, id.

Otro de $N^{a} S^{a}$ de los Dolores, como de media vara.

(...)

Cancela de hierro con cerrojo y llaves.

Esta capilla a cargo de la familia de D. Francisco Díaz García. (...).

Para los efectos oportunos, lo firmo y sello en Gilena, a 19 de junio de 1886.

Antonio Gutiérrez y Quevedo. 


\section{INVENTARIO DE LA IGLESIA PARROQUIAL DE LA INMACULADA CONCEPCIÓN DE GILENA (1928) ${ }^{89}$}

Inventario general de la parroquia de la Purísima Concepción de Gilena, siendo curra párroco de ella D. Manuel González Caballero, presbitero.

Puerta mayor pintada en verde con dos postigos, cada cual con su cerradura y llave.

Un cancel con dos postigos laterales (...).

Capilla del bautismo con puerta de entrada o cancela de madera pintada en azul; una pila grande de piedra y otra pequeña, también de piedra, dentro de la anterior; una ventana con rejas, puertas de cristales (...); un cuadro pequeño de lienzo de media vara de largo que representa a San Juan Bautista bautizando en el Jordán a Jesús, sin ningún valor artístico.

Dos pilas para agua bendita, al parecer, la concha con pie de mármol.

Puerta de madera que da entrada a la escalera que sube al coro (...).

Coro alto con baranda de hierro, una claraboya redonda que da a la calle (...); un órgano con 18 registros, con faltas de pitos y desafinado, un depósito para aire y dos fuelles para alimentar el depósito, una banquilla para el organista, una rueda con varias campanitas para tocarlas cuando se alza en la Santa Misa.

Una puerta para la torre, a la que se sube por una escalera de caracol de madera en mal estado. Una torre como de unos 30 metros de alta con cuatro arcos, en cada uno de ellos una campana, dos grandes y dos más pequeñas, en buen uso; cuatro balcones, uno en cada $\operatorname{arco}(. .$.$) .$

Nave central. Capilla Mayor.

Retablo de madera pintado en blanco, azul y dorado; a los lados, dos repisas con las imágenes de S. Pedro y S. Pablo, de talla, como de 1 vara; camarin bastante espacioso con embocadura a la iglesia

89 AGAS, Administración, Inventarios, legajo 693 (14.556). 
(...) en su centro la imagen de la Purisima Concepción, de vestir, sobre trono dorado; (...) dos cuadros de lienzo tamaño 2 varas cada uno con molduras pintadas y doradas, de poco mérito artístico, uno de ellos representa a Cristo Crucificado y el otro la Sagrada Familia; (...).

En la nave central y al lado del Evangelio se encuentra un púlpito de hierro con escalerilla de madera y tornavoz de madera tallada; (...).

Al lado del Evangelio, hay una nave colateral, en cuyo frente se encuentra la capilla del Sagrario con un retablo de madera tallado y dorado, altar de material con una frontalera de una pieza de piedra jaspeada con el escudo del Carmen en el centro (...) en el centro un Sagrario dorado (...). En el lado del evangelio hay una puerta que por una escalera conduce al camarin en el que se encuentra la imagen de $N^{a} S^{a}$ del Carmen, como de 1 metro de alta, con el Niño Jesús en los brazos, es imagen de vestir y está montada sobre un pedestal pintado. En la parte superior del retablo se halla un cuadro de San Rafael incrustado en el mismo retablo. Al lado del evangelio, hay un cuadro de lienzo de ningún valor artístico que representa a la Virgen del Carmen y delante del altar, a cierta distancia, hay una baranda de hierro. (...)

A continuación y a la derecha está el altar de $N^{a} S^{a}$ de los Dolores, con retablo de madera tallada y pintado de varios colores (...); una urna de caoba pequeña con cristal que encierra los Sagrados Corazones de Jesús y María. A los lados del altar y en sus repisas dos estatuas, como de 1 vara, de talla, que representan una a San Agustín y la otra a San Luis. A la izquierda del altar una puerta que conduce al camarin en donde se encuentra una imagen de $N^{a} S^{a}$ de los Dolores, de vestir, sobre trono de madera tallada, y sobre la embocadura del camarín un Ángel de talla suspenso al retablo y por encima del retablo una ventana grande con cristales (...).

A continuación se encuentra el altar de San Francisco de Asís, de madera tallada y dorada, altar de madera de repisa tallado y en el centro del retablo un nicho en donde se encuentra San Francisco, como de 1 metro de altura, de madera tallada, con una bandera de metal blanco en la mano derecha y un crucifijo en la izquierda. (...). 
En el centro del altar un tabernáculo o sagrario antiguo donde están encerradas las anforitas de los santos óleos. (...)

A la derecha de San Francisco y dando frente al altar del Sagrario o de $N^{a} S^{a}$ del Carmen, hay un altar, llamado de San Antonio, todo de mampostería y yeso, con un nicho en el centro donde se encuentra San Antonio de Padua, de poco más de 1 vara con el Niño en los brazos. El retablo es de yeso moldeado sin pintar ni dorar.

Continuando la dirección hacia la puerta principal de la iglesia, a la derecha se encuentra la capilla de la Santisima Trinidad, propiedad de los hijos y herederos de D. Francisco Diaz Garcia, su fundador. Es una capilla cuadrada, bastante espaciosa, con un altar de frente donde se venera la Santisima Trinidad, esculturas de talla, en un retablo de madera pintado en blanco y los filetes dorados. El altar es de mármol blanco con pie de altar de madera. Al final del retablo un cuadro que representa a San José con el Niño, de mediano mérito artistico. Sobre una mesa, al lado de la epistola, se halla la imagen de Santa Ana y la Santisima Virgen Niña, de tamaño natural, de madera tallada y pinturas del vestido estofadas. Al lado del evangelio se halla otra mesa y sobre ella San Joaquín con la Virgen Niña en los brazos, tamaño natural, de madera tallada y vestidos pintados y estofados. En el frente colateral del lado del Evangelio se encuentra un altar de madera con la imagen de San Francisco de Paula de madera tallada (el altar no se utiliza para decir misa por estar ocupado con el pedestal del santo). Frente a este altar se encuentra el altar del Sagrado Corazón de Jesús, en un nicho incrustado en la pared: esta imagen mide vara y media, con pedestal y todo, es escultura moderna, donada por el que fue cura párroco de esta iglesia D. Antonio Gutiérrez Quevedo, el altar es una mesa larga de madera pintada en blanco. También se halla sobre una mesa de madera más pequeña una urnita de madera dorada con cristales y dentro un Niño Jesús pequeñito de vestir. Hay además encima de esta urnita y colgado de la pared un Cristo como de medio metro, bajo dosel y seis cuadros de lienzo de diferentes tamaños y mediano mérito artístico. (...). Hay además enterramiento subterráneo en esta capilla propiedad de los señores Diaz. Todo lo anteriormente expuesto queda custodiado por una gran verja de hierro a la entrada de la capilla. 
En la nave central se encuentra también un cuadro que representa el martirio de San Bartolomé, como de dos tercias de vara de alto, sin ningún valor artístico; cuatro cuadros de lienzo, como de vara y media de alto que representan otros tantos santos de la Iglesia. Un sepulcro de madera tallada y dorada, con cristales, donde se encierra el cuerpo de Jesús, con colchón de raso y almohada y colcha para taparlo. Un cuadrito con el Señor de la Redención, con cristal, como de media vara de alto.

Al lado izquierdo de altar mayor, o sea, al lado de la epistola, se encuentra la nave del Rosario o nave nueva, teniendo en su frente, en la parte opuesta a la puerta de la iglesia, un altar titulado del Rosario, con retablo hasta el techo dorado y altar de mamposteria con frontis de mármol o jaspe en dos piezas y rodeado de una verja de hierro como de dos metros de alta, con su puerta y cerrojo. En el centro de este retablo hay un hueco o nicho en donde se encuentra $N^{a} S^{a}$ del Rosario, de madera tallada, con el Niño en los brazos. (...). Entre este altar y el de San Juan hay una puerta de madera tallada que conduce a la sacristia, y a continuación un nicho en la pared donde se encuentra a San Juan Evangelista, escultura de vestir, como de vara y media, nicho pintado y altar de repisa de madera (...). A continuación se encuentra una puerta que da entrada al camarín de N. P. Jesús Nazareno, bastante espacioso, en donde se halla dicha imagen sobre un pedestal o tarima de madera, imagen de vestir de mediano mérito, de tamaño natural, con la cruz a cuestas. El retablo es de madera tallada en blanco y el altar también de madera tallada. (...). Frente a este altar se encuentra el altar llamado de Ánimas, de madera tallada y pintado, teniendo en su centro un cuadro de lienzo pintado, como de vara y media de alto, que representa a Cristo Crucificado y al lado derecho la Virgen del Carmen sacando ánimas del Purgatorio; altar de repisa de madera tallada y pintado (...).

A continuación del altar de Jesús Nazareno está el altar de San José, con retablo de madera y altar también de madera, tallados y pintados; en la parte superior del retablo hay un nichito en donde hay un Crucifijo de pasta, de ningún valor artistico, con cristal por delante; $y$ en el centro del retablo hay un nicho en donde se encuentra San José con el Niño de la mano, al parecer de madera tallada ambos. (...) 
Sigue a continuación una puerta grande que conduce a la calle, pintada en verde, con un postigo, llamada del Sol; esta puerta tiene cancel de madera en muy malas condiciones y una pilita pequeña al lado de piedra blanca para el agua bendita.

A continuación hay una habitación con puertas de madera pintadas donde se conserva y custodia el Monumento para el Jueves Santo.

Hay en esta iglesia también una urna o tabernáculo sin cristales y dentro una imagen del Sagrado Corazón de Jesús, todo sobre una mesa de madera. (...)

En la sacristía se encuentran cuatro cuadros de lienzo, uno como de dos varas de largo con marco de madera dorado que representa el rapto de San Francisco; otro representa el Purgatorio; otro representa a Jesús y está en tan mal estado que apenas se conoce la pintura y el otro es San José, un cuadro ordinario o de batalla sin valor ninguno; otro cuadrito pequeño de papel con San Juan Nepomuceno.

$$
\text { (...) }
$$

Hasta aqui los objetos que se encuentran dentro de esta iglesia de mi cargo, excepto los cálices, copones y demás objetos de valor que están depositados en la casa donde vive el Sacristán, así como otros varios objetos y alhajas que, como se ve en los inventarios adjuntos, se hallan para su conservación y custodia en las casas de las Señoras nombradas por su piedad y afecto a ciertas imágenes, camareras y depositarias de dichos objetos, por no haber en esta iglesia dependencias donde conservarlos (...).

Y para que conste expido el presente en Gilena a 20 de enero de 1928.

El párroco, Manuel González Caballero. 


\section{FUENTES Y BIBLIOGRAFÍA}

\section{A. Fuentes (manuscritas e impresas)}

- Archivo General del Arzobispado de Sevilla (AGAS):

- Serie Administración, Inventarios, legajo 693 (14.556).

- Serie Gobierno, Asuntos despachados, legajos 329 y 04818.

- Serie Vicaría de Estepa, legajo 14.556.

- Archivo Parroquia de Santa María de Estepa, Libro de Entierros n ${ }^{\circ}$ 9, f. 256.

- El Eco de Estepa, números 483 (27/02/1892), 488 (02/04/1892), 494 (14/05/1892), 495 (21/05/1892), 546 (13/05/1893), 595 (21/04/1894) y 613* (27/07/1895).

\section{B. Bibliografia}

- AGUILAR Y CANO, Antonio Memorial Ostipense, Estepa, 1886-1888, reedición facsímil: Estepa, 2014.

- ARANDA DONCEL, Juan, "Colegiales estepeños en la Asunción de Córdoba durante los siglos XVIII y primeros lustros del XIX”, en VV. AA., Actas de las II Jornadas sobre Historia de Estepa. El Marquesado de Estepa, Estepa, 1996, pp. 105-120.

- CONTRERAS PÉREZ, Francisco, "La comarca de Estepa a la luz de los censos modernos (1857-1930)", en VV. AA., Actas de las II Jornadas sobre Historia de Estepa. El Marquesado de Estepa, Estepa, 1996, pp. 479-504.

- ESCALERA, Ma Encarnación, y PRIETO, Joaquín Octavio, "El patrimonio artístico religioso del marquesado de Estepa en los primeros años del siglo XVIII", en VV. AA., Actas de las III Jornadas sobre Historia de Estepa. Patrimonio histórico, Estepa, 1998, pp. 597-608.

- FERNÁNDEZ FLORES, José, Vere Nullius. La Vicaria de Estepa, Estepa, 2000. 
- GARZA CORTÉS, Rosario, La villa de Estepa al final del dominio santiaguista, Estepa, 1996.

- JORDÁN FERNÁNDEZ, Jorge Alberto, "La exclaustración de 1835-37 en la Vicaria de Estepa", en VV. AA., Actas de las IV Jornadas sobre Historia de Estepa. La vicaría eclesiástica de Estepa, Estepa, 2000, pp. 353-380.

- MARTÍN RIEGO, Manuel, "La situación material y económica del clero parroquial de la Vicaria de Estepa a finales del siglo XVIII e inicios del XIX”, en VV. AA., Actas de las I Jornadas sobre Historia de Estepa, Estepa, 1995, pp. 347-358.

—, "El clero parroquial de la Vicaria de Estepa (siglos XVIII y XIX)", en VV. AA., Actas de las IV Jornadas sobre Historia de Estepa. La vicaria eclesiástica de Estepa, Estepa, 2000, pp. 163-200.

-, "Ordenados a titulo de patrimonio en la Vicaría Nullius de Estepa (1800-1874), en Anuario de Historia de la Iglesia Andaluza, vol. VI (2013) pp. 139-184.

- MORALES PADRÓN, Francisco (coord.), Catálogo de los Archivos Parroquiales de la Provincia de Sevilla, Sevilla, 1992, t. I, p. 543

- PEINADO SANTAELlA, Rafael G., "Estepa en la Edad Media (7111559)", en VV. AA., Actas de las I Jornadas sobre Historia de Estepa, Estepa, 1995, pp. 149-186.

- PRIETO PÉREZ, Joaquín Octavio, El Marquesado de Estepa (1751) según las Respuestas Generales del Catastro de Ensenada, Madrid, 1996.

- REINA, Jesús Ma y REINA, José, Aproximación a la Historia de Gilena (siglos XVIII, XIX y XX), Gilena, 2001.

- REINA, Margarita y CASTRO, Marcial de, "Panorámica de los procesos histórico demográficos de Gilena desde el siglo XVIII hasta el siglo XX", en VV. AA., Actas de las IV Jornadas sobre Historia de Estepa. La Vicaría eclesiástica de Estepa, Estepa, 2000, pp. 397-419.

- RUBIO SÁNCHEZ, Ma Soledad, El Colegio-Universidad de Osuna (15481824), reedición: Osuna, 2006.

-VV. AA. Catálogo arqueológico y artístico de la provincia de Sevilla, t. IV, Sevilla, 1955. 